\title{
ARTICLE
}

\section{gem-Dimethyl-substituted bis(imino)dihydroquinolines as thermally stable supports for highly active cobalt catalysts that produce linear PE waxes}

Received 00th January 20xx Accepted 00th January 20xx DOI: $10.1039 / x 0 \times x 00000 x$

\author{
Randi Zhang, a,b Yongfeng Huang, ${ }^{a, c}$ Gregory A. Solan*,a,d Wenjuan Zhang, ${ }^{e,}{ }^{*}$ Xinquan Hu, ${ }^{c, *}$ Xiang \\ Hao, ${ }^{a}$ and Wen-Hua Sun ${ }^{*, a, b}$ \\ Six types of 2,8-bis(imino)-7,7-dimethyl-5,6-dihydroquinoline, 2-( $\mathrm{ArN}=\mathrm{CMe})-8-(\mathrm{ArN})-7,7-\mathrm{Me}_{2} \mathrm{C}_{9} \mathrm{H}_{6} \mathrm{~N}\left(\mathrm{Ar}^{2}=2,6-\mathrm{Me}_{2} \mathrm{C}_{6} \mathrm{H}_{3} \mathbf{~ \mathbf { ~ L }}\right.$, \\ 2,6- $\mathrm{Et}_{2} \mathrm{C}_{6} \mathrm{H}_{3} \mathrm{L2}, 2,6-{ }^{-} \mathrm{Pr}_{2} \mathrm{C}_{6} \mathrm{H}_{3} \mathrm{L3}, 2,4,6-\mathrm{Me}_{3} \mathrm{C}_{6} \mathrm{H}_{2} \mathrm{~L}$ L, 2,6- $\mathrm{Et}_{2}-4-\mathrm{MeC}_{6} \mathrm{H}_{2} \mathbf{L 5}, 2,4,6-{ }^{\mathrm{B}} \mathrm{Bu}_{3} \mathrm{C}_{6} \mathrm{H}_{3} \mathbf{L 6}$ ), distinguishable by their steric and \\ electronic profile, are described that can readily undergo complexation with cobaltous chloride to form their \\ corresponding $\mathrm{LCoCl}_{2}$ chelates, Co1 - Co6. The molecular structures of $\mathrm{Co} 2$ and $\mathrm{Co3}$ reveal square pyramidal geometries \\ with ring puckering a feature of the gem-dimethyl section of their unsymmetrical $N, N, N^{\prime}$-ligands. On activation with either \\ methylaluminoxane (MAO) or modified methylaluminoxane (MMAO), all the cobalt complexes exhibited exceptionally \\ high activities for ethylene polymerization with levels reaching up to $1.19 \times 10^{7} \mathrm{~g} \mathrm{PE} \mathrm{mol}^{-1}$ (Co) $\mathrm{h}^{-1}$ for mesityl-containing \\ Co4. Significantly, these catalysts exhibited good thermal stability by displaying their optimal performance at temperatures \\ up to $70^{\circ} \mathrm{C}$ whilst also maintaining appreciable catalytic lifetimes. With the exception of that obtained using the most \\ sterically hindered $\operatorname{Co} 6$ (2,4,6-t-butyl), the polyethylenes are of low molecular weight $\left(M_{\mathrm{w}} \leq 16.0 \mathrm{~kg} \mathrm{~mol}^{-1}\right)$ and of narrow \\ dispersity $\left(M_{\mathrm{w}} / M_{\mathrm{n}} \leq 3.4\right)$. Moreover, end-group analysis of these highly linear polymer waxes reveals evidence for \\ unsaturated as well as various levels of fully saturated materials highlighting the role of both $\beta$ - $\mathrm{H}$ elimination and chain \\ transfer to aluminum as termination pathways.
}

\section{Introduction}

The proficiency of molecular iron and cobalt catalysts to promote ethylene chain growth by affording low molecular weight $\alpha$-olefins through to high molecular linear polyethylene, has been the subject of on-going interest for more than twenty years. ${ }^{1-17}$ One reason for this sustained attention can be attributed to the amenability of this catalyst class to straightforward ligand modification that can impact on not only catalytic activity but also on the thermal stability and molecular weight of the resultant hydrocarbon-based materials. Indeed, numerous structural variations to the

a. Key Laboratory of Engineering Plastics and Beijing National Laboratory for Molecular Sciences, Institute of Chemistry, Chinese Academy of Sciences, Beijing 100190,China.E-mail:whsun@iccas.ac.cn

b. CAS Research/Education Center for Excellence in Molecular Sciences and International School, University of Chinese Academy of Sciences, Beijing 100049, China.

College of Chemical Engineering, Zhejiang University of Technology, Hangzhou 310014, China.

d. Department of Chemistry, University of Leicester, University Road, Leicester LE1 7RH, UK.E-mail: gas8@leicester.ac.uk

e. Beijing Key Laboratory of Clothing Materials R\&D and Assessment, Beijing Engineering Research Center of Textile Nanofiber, School of Materials Science and Engineering, Beijing Institute of Fashion Technology, Beijing 100029, China. tElectronic Supplementary Information (ESI) available: CCDC 1897122 and 1897123 contain the supplementary crystallographic data for compounds Co2 and Co3. These data can be obtained free of charge via www.ccdc.cam.ac.uk/data_request/cif. prototypical bis(arylimino)pyridine-metal precatalysts (A, Chart 1) have been performed including to the substituents belonging to the $\mathrm{N}$-aryl groups and to the imino-carbon atoms. ${ }^{18-27}$

As a further variable introduced by our group and others is the degree of ring strain present in the bis(imino)pyridine framework. Indeed by fusing one or two carbocyclic rings to the central pyridine unit, a wide variety of complexes have now been reported including those based on 1,8-diimino2,3,4,5,6,7-hexahydroacridines (B, Chart 1), ${ }^{28}$ 2-(1(arylimino)ethyl)- 8-arylimino-5,6,7-trihydroquinolines (C), 29-31 2-(1-(arylimino)ethyl)-7-arylimino-6,6-dimethyl

cyclopentapyridines (D, Chart 1$)^{32}$ and 2-(1-arylimino)ethyl-9arylimino-5,6,7,8-tetrahydro-cycloheptapyridines (E). ${ }^{33-36}$ With particular regard to cobalt, the fused 6-membered ring precatalysts $\mathbf{B}$ and $\mathbf{C}$ have shown improved temperature stability and higher activity when compared with the parent bis(imino)pyridine systems. By comparison, the 5-membered ring system $\mathbf{D}$ is significantly less active while the 7-membered ring $\mathbf{E}$ has displayed higher activity, a longer catalyst lifetime along with reasonable thermal stability. Elsewhere, the substitution of the arylimine unit in cobalt-containing $\mathbf{C}$ with a benzimidazole group has seen the development of short chain oligomerization catalysts that can be modulated by choice of co-catalyst. ${ }^{31}$ 

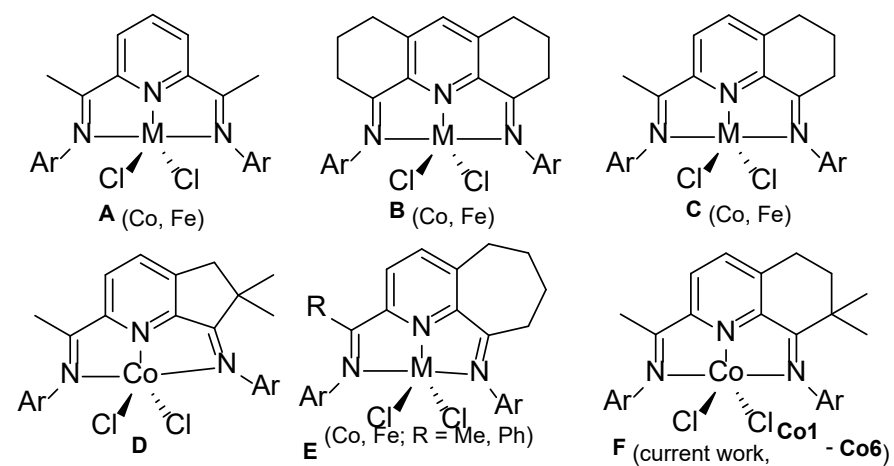

Chart 1 Bis(imino)pyridine-containing $\mathbf{A}$ and its fused derivatives $\mathbf{B}-\mathbf{F}$

In this paper, we target a new series of divalent cobalt chloride complexes bearing 2-(1-(arylimino)ethyl)-8-arylimino7,7-dimethyl-5,6-dihydroquinolines (F, Chart 1$)$, in which a singly fused six-membered ring is appended with two methyl groups at the C-7 position. It was of interest to explore how this gem-dimethyl substitution would impact on the catalytic activity, temperature stability and polymer properties when compared with that observed using unsubstituted $\mathbf{C}$ and other ring sizes. Six distinct examples of $\mathbf{F}$ are disclosed in which the substitution pattern of the $\mathrm{N}$-aryl group has been systematically varied (aryl $=2,6-\mathrm{Me}_{2} \mathrm{C}_{6} \mathrm{H}_{3}, 2,6-\mathrm{Et}_{2} \mathrm{C}_{6} \mathrm{H}_{3}, 2,6$ $\left.{ }^{i} \mathrm{Pr}_{2} \mathrm{C}_{6} \mathrm{H}_{3}, 2,4,6-\mathrm{Me}_{3} \mathrm{C}_{6} \mathrm{H}_{2}, 2,6-\mathrm{Et}_{2}-4-\mathrm{MeC}_{6} \mathrm{H}_{2}, 2,4,6-{ }^{t} \mathrm{Bu}_{3} \mathrm{C}_{6} \mathrm{H}_{3}\right)$. A detailed investigation of the performance of these complexes as precatalysts for ethylene polymerization is undertaken with two types of co-catalyst to ascertain not only the activity and thermostability of the catalyst but also the effect on the properties of the polyethylene produced (e.g., molecular weight, dispersity, linearity and end-group composition). In addition, full characterization is presented for six new ligands and their resulting complexes.

\section{Results and discussion}

\section{Synthesis and characterization of Co1 - Co6}

The free 2-(1-(arylimino)ethyl)-8-arylimino-7,7-dimethyl-5,6dihydroquinolines, 2-( $\mathrm{ArN}=\mathrm{CMe})-8-(\mathrm{ArN})-7,7-\mathrm{Me}_{2} \mathrm{C}_{9} \mathrm{H}_{6} \mathrm{~N} \quad(\mathrm{Ar}=$ 2,6- $-\mathrm{Me}_{2} \mathrm{C}_{6} \mathrm{H}_{3}$ L1, 2,6- $-\mathrm{Et}_{2} \mathrm{C}_{6} \mathrm{H}_{3}$ L2, 2,6- ${ }^{-} \mathrm{Pr}_{2} \mathrm{C}_{6} \mathrm{H}_{3}$ L3, 2,4,6- $-\mathrm{Me}_{3} \mathrm{C}_{6} \mathrm{H}_{2}$ L4, 2,6- $-\mathrm{Et}_{2}-4-\mathrm{MeC}_{6} \mathrm{H}_{2}$ L5, 2,4,6- ${ }^{-} \mathrm{Bu}_{3} \mathrm{C}_{6} \mathrm{H}_{3}$ L6), have been prepared in reasonable yield ( $46-59 \%)$ by the acid catalyzed condensation reaction of 2-acetyl-7,7-dimethyl-5,6dihydroquinolin-8-one with two equivalents of the corresponding aniline in 1,2-dichlorobenzene at reflux (Scheme 1). Initial attempts to perform the condensation reactions in $n$-butanol or xylene gave lower yields of the target compounds along with substantial amounts of the corresponding imine-ketone intermediate. Ketone $\mathbf{3}$ is not readily available and was synthesized in a two-step procedure 32,37 by firstly gem-dimethylating 2-chloro-5,6,7trihydroquinolin-8-one (1) at the 7-position to give 2-chloro7,7-dimethyl-5,6-dihydroquinolin-8-one (2) and then converting $\mathbf{2}$ to $\mathbf{3}$ via a palladium mediated Stille cross coupling approach.

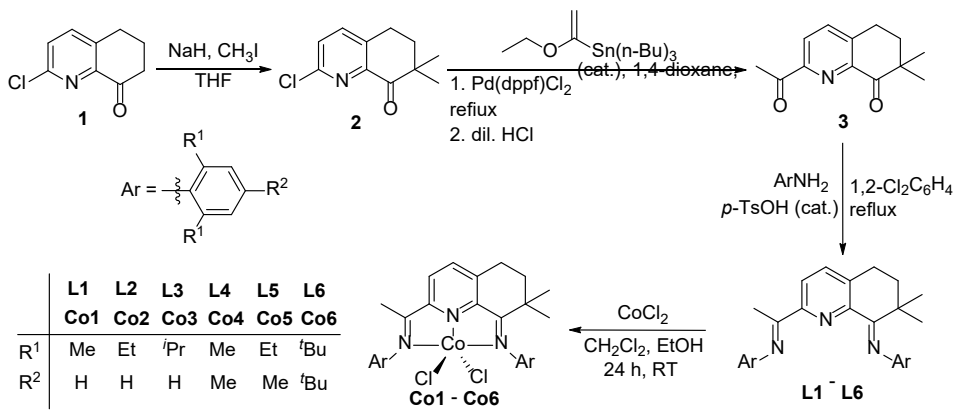

Scheme 1 Synthetic route to L1 - L6 and Co1 - Co6.

Subsequent reaction of $\mathbf{L} \mathbf{1}$ - $\mathbf{L} \mathbf{6}$ with one molar equivalent of $\mathrm{CoCl}_{2}$ in a mixture of ethanol and dichloromethane at room temperature gave [2-( $\left.\mathrm{ArN}=\mathrm{CMe})-8-(\mathrm{ArN})-7,7-\mathrm{Me}_{2} \mathrm{C}_{9} \mathrm{H}_{6} \mathrm{~N}\right] \mathrm{CoCl}_{2}$ $\left(\mathrm{Ar}=2,6-\mathrm{Me}_{2} \mathrm{C}_{6} \mathrm{H}_{3}\right.$ Co1, 2,6- $\mathrm{Et}_{2} \mathrm{C}_{6} \mathrm{H}_{3} \mathrm{Co2}, 2,6-{ }^{i} \mathrm{Pr}_{2} \mathrm{C}_{6} \mathrm{H}_{3} \mathrm{Co3}$, 2,4,6- $\left.\mathrm{Me}_{3} \mathrm{C}_{6} \mathrm{H}_{2} \mathrm{Co} 4,2,6-\mathrm{Et}_{2}-4-\mathrm{MeC}_{6} \mathrm{H}_{2} \mathrm{Co5}, 2,4,6-{ }^{t} \mathrm{Bu}_{3} \mathrm{C}_{6} \mathrm{H}_{3} \mathrm{Co} 6\right)$ in good yields ( $59-84 \%$, Scheme 1$)$. All organic compounds and complexes have been characterized by FT-IR spectroscopy and elemental analysis. In addition, $\mathrm{Co} 2$ and $\mathrm{Co} 3$ have been the subject of single crystal X-ray diffraction studies.

Crystals of $\mathrm{Co} 2$ and $\mathrm{Co} 3$ suitable for the X-ray studies were grown by slow diffusion of hexane into a dichloromethane solution of the corresponding complex. Perspective views of $\mathrm{Co2}$ and $\mathrm{Co} 3$ are shown in Figures 1 and 2; selected bond lengths and angles are listed in Table 1 . In each case the cobalt center is surrounded by three nitrogen atoms belonging to the chelating 2,8-diarylimino-7,7-dimethyl-5,6-dihydroquinoline (aryl = 2,6-diethylphenyl Co2, 2,6-diisopropylphenyl Co3) and two chloride ligands to complete a five-coordinate geometry. Closer examination reveals that this geometry can be best described as distorted square pyramidal with the three nitrogen atoms and one chloride atom $(\mathrm{Cl} 1)$ forming the basal plane and $\mathrm{Cl} 2$ filling the apical position. The cobalt atom sits at a distance of $0.519 \AA$ above the basal plane for $\mathbf{C o 2}$ and 0.523 $\AA$ for $\mathrm{Co3}$ in a manner similar to that observed in related $(N, N, N) \mathrm{CoCl}_{2}$ species. ${ }^{29,33,35}$ There are some differences in the three cobalt-nitrogen distances with $\mathrm{Co}-\mathrm{N}_{\text {pyridine length the }}$ shortest [2.103(2) A Co2, 2.052(4) ^̊ Co3], while the exterior Co- $\mathrm{N}_{\text {imine }}$ bond lengths though longer, show some additional variation with that involving the fused six-membered ring the

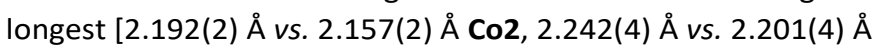
Co3]. These variations highlight the more effective coordination of the central pyridine $\mathrm{N}$ atom and also the constraint imposed by the fused ring on the exterior Co- $\mathrm{N}_{\text {imine }}$ distance. Between molecules, it is apparent that the more sterically demanding 2,6-diisopropylphenyl groups in Co3 exert an elongating effect on the Co- $\mathrm{N}_{\text {imine }}$ distances with their values on average $0.047 \AA$ longer than that seen in Co2. Furthermore, it can be seen that the $\mathrm{N}$-aryl substitution pattern also has some effect on the bond angles associated with the gem-dimethyl groups with the C12-C9-C13 angle in Co2 $\left(110.7(3)^{\circ}\right)$ discernibly larger than that in $\operatorname{Co3}\left(108.3(5)^{\circ}\right)$. As expected the C7-C8-C9 sections of each fused six- 
membered ring are puckered on account of their $\mathrm{sp}^{3}$ hybridization displayed by each of these three carbon atoms. In both structures the $\mathrm{N}$-aryl groups are inclined essentially orthogonally to the coordination plane with dihedral angles ranging from $71.68^{\circ}$ to $82.37^{\circ}$ for $\mathrm{Co2}$ and $84.33^{\circ}$ to $88.22^{\circ}$ for Co3, respectively. There are no intermolecular contacts of note.

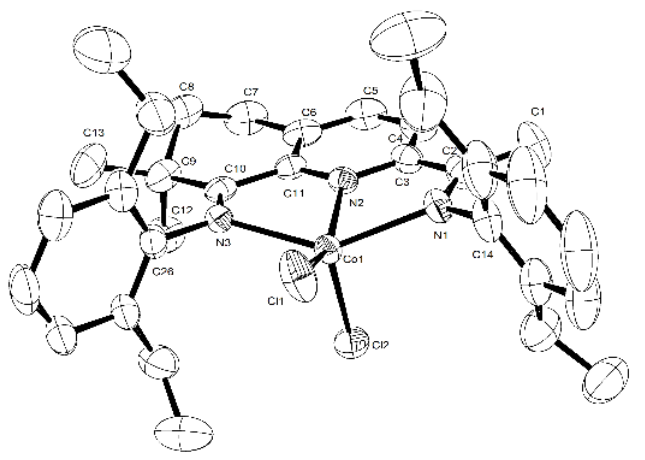

Figure 1 OLEX2 representation of Co2 with the thermal ellipsoids shown at the 50\% probability level; all hydrogen atoms have been omitted for clarity.

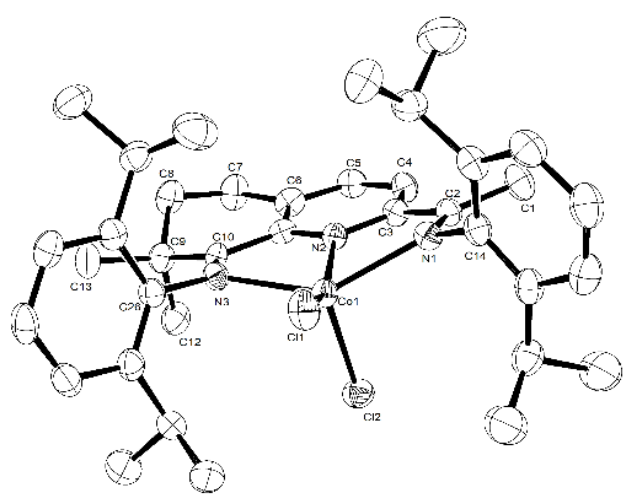

Figure 2 OLEX2 representation of $\mathrm{Co} 3$ with the thermal ellipsoids shown at the 50\% probability level; all hydrogen atoms and two molecules of $\mathrm{CH}_{2} \mathrm{Cl}_{2}$ have been omitted for clarity.

Strong absorption bands around $1610 \mathrm{~cm}^{-1}$ are a feature of the IR spectra of Co1 - Co6 which are typical of bound imine nitrogen atoms and indeed around $30 \mathrm{~cm}^{-1}$ less than that observed in the free ligands. ${ }^{14,19,28-33}$ Further support for the composition of complexes is provided by their microanalytical data.

\section{Catalyst Evaluation for Ethylene Polymerization}

In previous work, the cobalt(II) chloride complexes A - E (Chart 1) have been shown to exhibit their optimal performance as precatalysts for ethylene polymerization when using either methylaluminoxane (MAO) or modified MAO (MMAO) as cocatalyst. ${ }^{28-35}$ Thus, the current investigation focuses on these two types of co-catalyst using 2,6-dimethylphenyl-containing Co1 as the test precatalyst. Optimization of the Al:Co molar ratio, reaction temperature and ethylene pressure as well as studies concerned with catalyst lifetime will be performed independently using Co1/MAO and Co1/MMAO, before a comparative evaluation is performed on the remaining precatalysts, Co2 - Co6 (Tables 2 and 3). In all cases the polymeric products will be characterized by using GPC and DSC and, in selected cases, by high temperature NMR spectroscopy. As a matter of course, GC will be used to detect for any oligomeric material present in the polymerization solutions.

(a) Ethylene polymerization using Co1 - Co6/MAO. With MAO as the co-catalyst, the effect of reaction conditions on the performance of Co1 was initially investigated in order to obtain a set of conditions that could be applied to Co2 - Co6; the full set of results are collected in Table 2 .

Table 1 Selected bond lengths $(\AA)$ and angles $\left({ }^{\circ}\right)$ for $\mathrm{Co} 2$ and $\mathrm{Co} 3$

\begin{tabular}{|c|c|c|}
\hline & $\mathrm{Co2}$ & Co3 \\
\hline \multicolumn{3}{|c|}{ Bond lengths $(\AA)$} \\
\hline $\mathrm{Co}(1)-\mathrm{Cl}(1)$ & $2.3014(11)$ & $2.2642(15)$ \\
\hline $\mathrm{Co}(1)-\mathrm{Cl}(2)$ & $2.2584(9)$ & $2.3206(16)$ \\
\hline $\mathrm{Co}(1)-\mathrm{N}(1)$ & $2.157(2)$ & $2.201(4)$ \\
\hline $\mathrm{Co}(1)-\mathrm{N}(2)$ & $2.103(2)$ & $2.052(4)$ \\
\hline $\mathrm{Co}(1)-\mathrm{N}(3)$ & $2.192(2)$ & $2.242(4)$ \\
\hline$N(1)-C(2)$ & $1.333(4)$ & $1.285(6)$ \\
\hline$N(1)-C(14)$ & $1.411(4)$ & $1.453(6)$ \\
\hline$N(2)-C(3)$ & $1.352(4)$ & $1.340(6)$ \\
\hline$N(2)-C(11)$ & $1.314(3)$ & $1.342(6)$ \\
\hline$N(3)-C(10)$ & $1.307(4)$ & $1.298(6)$ \\
\hline$N(3)-C(26)$ & $1.483(4)$ & $1.451(6)$ \\
\hline \multicolumn{3}{|c|}{ Bond angles $\left({ }^{\circ}\right)$} \\
\hline $\mathrm{Cl}(1)-\mathrm{Co}(1)-\mathrm{Cl}(2)$ & $117.06(4)$ & $114.02(6)$ \\
\hline $\mathrm{N}(1)-\mathrm{Co}(1)-\mathrm{Cl}(1)$ & 101.94(7) & $97.07(12)$ \\
\hline $\mathrm{N}(1)-\mathrm{Co}(1)-\mathrm{Cl}(2)$ & $98.14(7)$ & $101.62(12)$ \\
\hline$N(1)-C o(1)-N(2)$ & $72.54(9)$ & $74.06(16)$ \\
\hline $\mathrm{N}(1)-\mathrm{Co}(1)-\mathrm{N}(3)$ & 141.59(9) & $140.28(16)$ \\
\hline $\mathrm{N}(2)-\mathrm{Co}(1)-\mathrm{N}(3)$ & 75.19(9) & $74.06(16)$ \\
\hline $\mathrm{N}(2)-\mathrm{Co}(1)-\mathrm{Cl}(1)$ & $152.67(7)$ & $154.48(13)$ \\
\hline $\mathrm{N}(2)-\mathrm{Co}(1)-\mathrm{Cl}(2)$ & $90.27(7)$ & $91.36(12)$ \\
\hline $\mathrm{N}(3)-\mathrm{Co}(1)-\mathrm{Cl}(1)$ & $97.19(7)$ & $101.60(11)$ \\
\hline $\mathrm{N}(3)-\mathrm{Co}(1)-\mathrm{Cl}(2)$ & $102.31(6)$ & $102.21(12)$ \\
\hline$C(12)-C(9)-C(13)$ & $110.7(3)$ & $108.3(5)$ \\
\hline$N(3)-C(10)-C(11)$ & $116.8(2)$ & $114.1(4)$ \\
\hline
\end{tabular}

With the ethylene pressure set at 10 atm and the Al:Co molar ratio at 2000, the influence of reaction temperature was firstly investigated by screening Co1/MAO between 30 and 90 ${ }^{\circ} \mathrm{C}$ (entries $1-7$, Table 2). The highest observed activity of $11.40 \times 10^{6} \mathrm{~g} \mathrm{PE} \mathrm{mol}^{-1}$ (Co) $\mathrm{h}^{-1}$ was achieved at $70{ }^{\circ} \mathrm{C}$, above which the activity was seen to dramatically decrease. This finding can likely be accredited to both decomposition of the active species ${ }^{38-40}$ and the lower concentration of ethylene in toluene at higher temperature. ${ }^{41-43}$ To explore the importance of the latter, adjusted activities are also provided in Table 2 that have been determined on the basis of the ethylene concentration ( $\left.C_{\text {ethylene, }} \mathrm{mol} \mathrm{L}^{-1}\right)$ under the particular conditions. In general, the adjusted activities display similar trends to those seen with the observed activity. Moreover, inspection of the data suggest that ethylene solubility in toluene is a key factor affecting the catalytic activity. ${ }^{44}$ In terms of the resulting polymeric materials, their molecular weights $\left(M_{\mathrm{w}}\right)$ appear in the range 12.87 to $0.93 \mathrm{~kg} \mathrm{~mol}^{-1}$ which are 
typical of polyethylene waxes. Inspection of their GPC curves indicates that the value of $M_{\mathrm{w}}$ steadily declines as the temperature is raised reaching its lowest value at $90{ }^{\circ} \mathrm{C}$ (Figure 3; see Figures S1 - S7), an observation that can be ascribed to either increased chain transfer to aluminum or chain termination by $6-\mathrm{H}$ elimination at the higher temperatures. ${ }^{14,19,28-34}$ Meanwhile, the molecular weight distribution remained relatively narrow $\left(M_{\mathrm{w}} / M_{\mathrm{n}}\right.$ range: $2.3-$ 2.7) over the temperature range consistent with an active species displaying single-site characteristics.

Table 2 Ethylene polymerization results obtained using $\mathrm{Co} 1$ - Co6/MAO ${ }^{a}$

\begin{tabular}{|c|c|c|c|c|c|c|c|c|c|c|}
\hline Entry & Precat. & Al:Co & $t(\min )$ & $\mathrm{T}\left({ }^{\circ} \mathrm{C}\right)$ & $\begin{array}{c}\text { Mass of } \\
\text { PE (g) }\end{array}$ & Activity $^{b}$ & $\begin{array}{l}\text { Adjusted } \\
\text { Activity }^{c}\end{array}$ & $M_{\mathrm{w}}{ }^{d}$ & $M_{\mathrm{w}} / M_{\mathrm{n}}^{d}$ & $T_{\mathrm{m}}{ }^{e}$ \\
\hline 1 & Co1 & 2000 & 30 & 30 & 2.43 & 2.43 & 1.93 & 12.87 & 2.59 & 131.0 \\
\hline 2 & Co1 & 2000 & 30 & 40 & 3.23 & 3.23 & 2.94 & 10.54 & 2.53 & 129.7 \\
\hline 3 & Co1 & 2000 & 30 & 50 & 3.43 & 3.43 & 3.55 & 7.59 & 2.29 & 128.7 \\
\hline 4 & Co1 & 2000 & 30 & 60 & 9.71 & 9.71 & 11.33 & 6.71 & 2.64 & 128.4 \\
\hline 5 & Co1 & 2000 & 30 & 70 & 11.40 & 11.40 & 14.94 & 5.11 & 2.35 & 126.5 \\
\hline 6 & Co1 & 2000 & 30 & 80 & 4.34 & 4.34 & 6.30 & 4.65 & 2.37 & 126.9 \\
\hline 7 & Co1 & 2000 & 30 & 90 & 2.68 & 2.68 & 4.31 & 0.93 & 2.70 & 126.9 \\
\hline 8 & Co1 & 1000 & 30 & 70 & 0.97 & 0.97 & 1.27 & 11.22 & 4.47 & 128.4 \\
\hline 9 & Co1 & 1500 & 30 & 70 & 1.06 & 1.06 & 1.39 & 8.12 & 2.88 & 128.0 \\
\hline 10 & Co1 & 1750 & 30 & 70 & 4.07 & 4.07 & 5.33 & 5.53 & 2.30 & 127.5 \\
\hline 11 & Co1 & 2250 & 30 & 70 & 7.39 & 7.39 & 9.69 & 4.71 & 2.44 & 127.8 \\
\hline 12 & Co1 & 2500 & 30 & 70 & 6.42 & 6.42 & 8.41 & 5.48 & 2.03 & 127.1 \\
\hline 13 & Co1 & 3000 & 30 & 70 & 4.71 & 4.71 & 6.17 & 4.56 & 2.30 & 126.1 \\
\hline 14 & Co1 & 2000 & 5 & 70 & 4.02 & 24.12 & 31.61 & 5.00 & 2.20 & 127.4 \\
\hline 15 & Co1 & 2000 & 15 & 70 & 6.51 & 13.02 & 17.06 & 5.00 & 2.18 & 127.0 \\
\hline 16 & Co1 & 2000 & 45 & 70 & 13.62 & 9.08 & 11.90 & 5.27 & 2.33 & 127.6 \\
\hline 17 & Co1 & 2000 & 60 & 70 & 13.85 & 6.93 & 9.08 & 5.80 & 2.46 & 127.5 \\
\hline 18 & $\mathrm{Co2}$ & 2000 & 30 & 70 & 6.22 & 6.22 & 8.15 & 13.95 & 2.55 & 130.6 \\
\hline 19 & $\mathrm{Co3}$ & 2000 & 30 & 70 & 0.51 & 0.51 & 0.67 & 15.88 & 3.44 & 131.4 \\
\hline 20 & Co4 & 2000 & 30 & 70 & 11.90 & 11.90 & 15.60 & 5.33 & 2.16 & 127.3 \\
\hline 21 & Co5 & 2000 & 30 & 70 & 7.65 & 7.65 & 10.03 & 14.90 & 2.50 & 130.9 \\
\hline 22 & Co6 & 2000 & 30 & 70 & 7.88 & 7.88 & 10.33 & 46.12 & 3.83 & 133.8 \\
\hline $23^{f}$ & Co1 & 2000 & 30 & 70 & 7.41 & 7.41 & - & 5.48 & 2.20 & 127.0 \\
\hline $24^{g}$ & Co1 & 2000 & 30 & 70 & 3.23 & 3.23 & - & 4.54 & 1.68 & 126.1 \\
\hline
\end{tabular}

a Conditions: $2.0 \mu \mathrm{mol}$ of prectalyst, $100 \mathrm{~mL}$ of toluene, $10 \mathrm{~atm} \mathrm{C}_{2} \mathrm{H}_{4} ;{ }^{b}$ Values in units of $10^{6} \mathrm{~g}(\mathrm{PE}) \mathrm{mol}^{-1}$ (Co) $\mathrm{h}^{-1} ;{ }^{c} 10^{6} \mathrm{~g}(\mathrm{PE}) \mathrm{mol}^{-1}(\mathrm{Co}) \mathrm{h}^{-1}$ $C_{\text {ethylene }}{ }^{-1} ;{ }^{d} M_{\mathrm{w}}: \mathrm{kg} \mathrm{mol}^{-1} . M_{\mathrm{w}}$ and $M_{\mathrm{w}} / M_{\mathrm{n}}$ determined by GPC; ${ }^{e}$ Determined by DSC; $f 5$ atm $\mathrm{C}_{2} \mathrm{H}_{4} ;{ }^{g} 1$ atm $\mathrm{C}_{2} \mathrm{H}_{4}$.

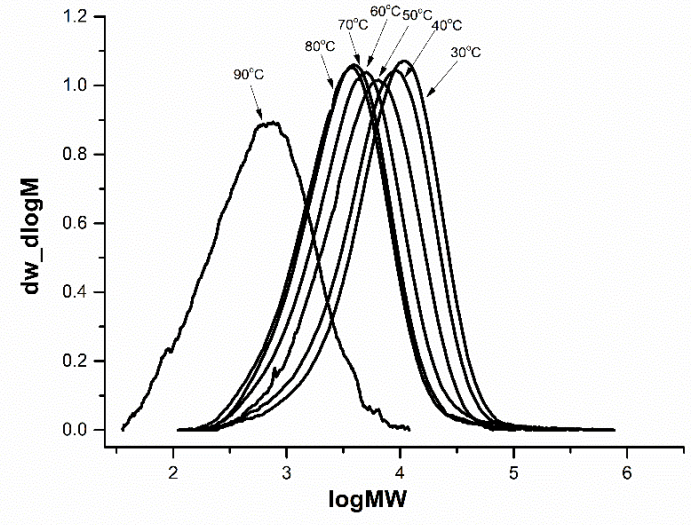

Figure 3 GPC traces of the polyethylenes obtained using Co1/MAO at differen reaction temperatures (entries $1-7$, Table 2 ).

Secondly with the temperature maintained at $70{ }^{\circ} \mathrm{C}$, the polymerizations using Co1 were investigated at different MAO ratios (Al:Co $=1000$ to 3000 ) revealing a maximum in catalytic activity at a ratio of 2000 (entries $5,8-13$, Table 2). At the lowest ratio of 1000 , the polyethylene with the highest molecular weight $\left(M_{\mathrm{w}}=11.22 \mathrm{~kg} \mathrm{~mol}^{-1}\right)$ was formed, while at the highest ratio (3000) the $M_{\mathrm{w}}$ decreased to its lowest value of $4.56 \mathrm{~kg} \mathrm{~mol}^{-1}$ (see Figures S8 - S13). This downward trend in molecular weight is likely due to the onset of chain transfer to aluminum at higher MAO concentrations. ${ }^{45-47}$ On the other hand, the molecular weight distribution remained reasonably narrow $\left(M_{\mathrm{w}} / M_{\mathrm{n}}\right.$ range: $\left.2.2-4.5\right)$ across the range of $\mathrm{Al}$ :Co ratios.

Thirdly, the lifetime of Co1/MAO was probed by conducting the polymerizations over $5,15,30,45$ and 60 min run times (entries 5 and $14-17$, Table 2). After $5 \mathrm{~min}$, the highest activity of $24.12 \times 10^{6} \mathrm{~g} \mathrm{PE} \mathrm{mol}^{-1}$ (Co) h-1 was achieved while after $15 \mathrm{~min}$ this value had substantially reduced to $13.02 \times$ $10^{6} \mathrm{~g} \mathrm{PE} \mathrm{mol}^{-1}$ (Co) $\mathrm{h}^{-1}$. On prolonging the reaction time further, the drop in activity was more gradual reaching its lowest value of $6.93 \times 10^{6} \mathrm{~g} \mathrm{PE} \mathrm{mol}^{-1}$ (Co) h $\mathrm{h}^{-1}$ after $60 \mathrm{~min}$ 
(entries 5, $15-17$, Table 2). These observations highlight that following a rapid induction period, the rate of polymerization assumed a more stable profile with only a modest loss of catalytic activity by the one hour mark; similar short induction periods have been noted elsewhere for cobalt catalysts. $31,33,48$ Furthermore, the molecular weights of the resultant polyethylenes steadily increased as the reaction time was extended (see Figures S14 - S17).

The effect of ethylene pressure on catalytic activity was also found to be significant. For example, lowering the ethylene pressure from 10 to $5 \mathrm{~atm}$, with the other parameters otherwise the same, saw the catalytic activity drop from 11.40 to $7.41 \times 10^{6} \mathrm{~g} \mathrm{PE} \mathrm{mol}^{-1}$ (Co) h-1 (entry 23 vs. 5, Table 2), while at $1 \mathrm{~atm}$, the activity decreased further to $3.23 \times 10^{6} \mathrm{~g} \mathrm{PE}$ $\mathrm{mol}^{-1}$ (Co) $\mathrm{h}^{-1}$ (entry 24, Table 2). On the other hand, the effect of these pressure variations on the molecular weight of the polyethylenes was far from clear with the values of $M_{\mathrm{w}}$ falling in a narrow range between 5.48 and $4.54 \mathrm{~kg} \mathrm{~mol}^{-1}$, (entry 24, Table 2). Nonetheless, the dispersities of the polymers remained narrow across these three pressures (see Figures S23 - S24).

Finally, the remaining five precatalysts, Co2 - Co6 were screened employing the optimized conditions established for Co1/MAO. Collectively, all the cobalt catalysts exhibited high activities at $70{ }^{\circ} \mathrm{C}$ (range: $0.51-11.90 \times 10^{6} \mathrm{~g} \mathrm{PE} \mathrm{mol}^{-1}(\mathrm{Co}) \mathrm{h}^{-1}$; entries 5, $18-22$, Table 2 ) and were found to decrease in the order: $\operatorname{Co} 4$ (2,4,6-trimethyl) > Co1 (2,6-dimethyl) > Co6 (2,4,6$t$-butyl) $>\operatorname{Co5}$ (2,6-diethyl-4-methyl) $>\operatorname{Co2}(2,6$-diethyl) $>\operatorname{Co} 3$ (2,6-diisopropyl). In terms of electronic effects, the observation that Co4 (2,4,6-trimethyl) was more active than Co1 (2,6-dimethyl) (entry 20 vs. 5, Table 2$)$ and that $\operatorname{Co5}(2,6-$ diethyl-4-methyl) more active than Co2 (2,6-diethyl) (entry 21 vs. 18, Table 2), highlights the positive effect played by the para-methyl group on catalytic activity; the improved solubility of these para-methyl species in the polymerization solvent could also be a contributing factor. ${ }^{12,29-30,47}$ Meanwhile, the steric properties imparted by the ortho-substituted $\mathrm{N}$-aryl groups also impact on catalytic activity with the least bulky methyl-substituted Co1 more active than its bulkier ethyl- and isopropyl-substituted counterparts (Co2 and Co3). This can explained by the steric hindrance of the ortho substituents affecting the rate of the ethylene coordination by hindering its approach to the metal center. ${ }^{19,30,33,35}$ Surprisingly however, the most bulky Co6 showed a higher activity than the ethyland isopropyl-containing $\mathbf{C o 2}$ and Co3. It is unclear as to this difference but may be due to the presence of the para-t-butyl group that can not only impart a greater positive inductive effect but can also improve the solubility of the precatalyst. Moreover, Co6/MAO gave the polymer with the highest molecular weight (46.12 kg mol-1; entry 22, Table 2), which highlights the role played by the sterically hindered $t$-butyl ortho-substituents in inhibiting chain transfer. ${ }^{29-35}$ This may be due to the fact that chain transfer (through either $\beta$-hydrogen elimination or transfer to aluminum) requires a four-centered transition state, which for Co6 is blocked by the bulky $t$-butyl ortho-substitutions. In all cases, the molecular weight distributions of the polyethylenes remained reasonably narrow and unimodal $\left(M_{\mathrm{w}} / M_{\mathrm{n}}\right.$ range: $\left.2.2-6.6\right)$, a feature that is commonplace for related $(N, N, N)$ cobalt catalysts (see Figures S18 - S22). ${ }^{19,28-33}$

(b) Ethylene polymerization using Co1 - Co6/MMAO. As a separate study, we also examined the effect of using modified methylaluminoxane (MMAO) as the co-catalyst to activate Co1 - Co6. As before, Co1 was employed to allow an optimization of the reaction parameters; the results obtained are tabulated in Table 3.

With the temperature of the run varied between 30 and 80 ${ }^{\circ} \mathrm{C}$ and the Al:Co molar ratio retained at 2000, the activity of Co1/MMAO was observed to peak at $4.59 \times 10^{6} \mathrm{~g}(\mathrm{PE}) \mathrm{mol}^{-1}(\mathrm{Co})$ $\mathrm{h}^{-1}$ at $60{ }^{\circ} \mathrm{C}$ (entries $1-6$, Table 3). Similarly, the adjusted activities also show an optimum temperature at $60{ }^{\circ} \mathrm{C}$, which compares to $70{ }^{\circ} \mathrm{C}$ seen using Co1/MAO. However, in common with MAO the molecular weights of the resultant polyethylenes decreased with an increase in the reaction temperature without any significant differences in dispersity (Figure 4; see Figure S25 - S30); facile chain transfer to the alkylaluminum at higher temperature can be again used to account for this finding. ${ }^{14,19,28-34}$

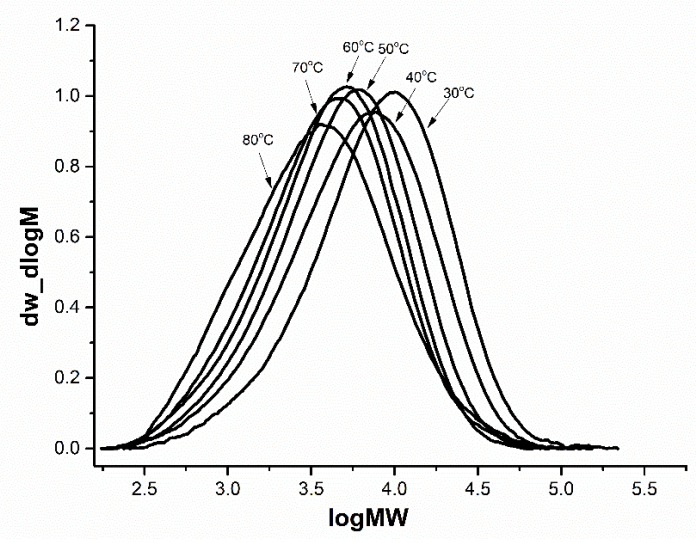

Figure 4 GPC traces of the polyethylenes obtained using Co1/MMAO at different reaction temperatures (entries $1-6$, Table 3 ).

Variations in the Al:Co molar ratio between 1000 and 3000, with the reaction temperature fixed at $60^{\circ} \mathrm{C}$, led to 2000 being identified as the optimum ratio for Co1/MMAO with a peak activity of $4.59 \times 10^{6} \mathrm{~g} \mathrm{PE} \mathrm{mol}^{-1}$ (Co) $\mathrm{h}^{-1}$ (entry 4 , Table 3 ). As a general observation, the higher molar ratios of MMAO gave lower molecular weight polyethylenes which is in line with more facile chain transfer occurring from the cobalt to aluminum. ${ }^{43,45-47}$ Nonetheless, the polyethylenes generated displayed fairly narrow dispersities $\left(M_{\mathrm{w}} / M_{\mathrm{n}}\right.$ range: $\left.2.2-4.5\right)$ which is supportive of single-site behavior at all ratios (see Figures S31 - S36). 


\section{ARTICLE}

Table 3 Ethylene polymerization results obtained using $\mathrm{Co1}$ - Co6/MMAO ${ }^{a}$

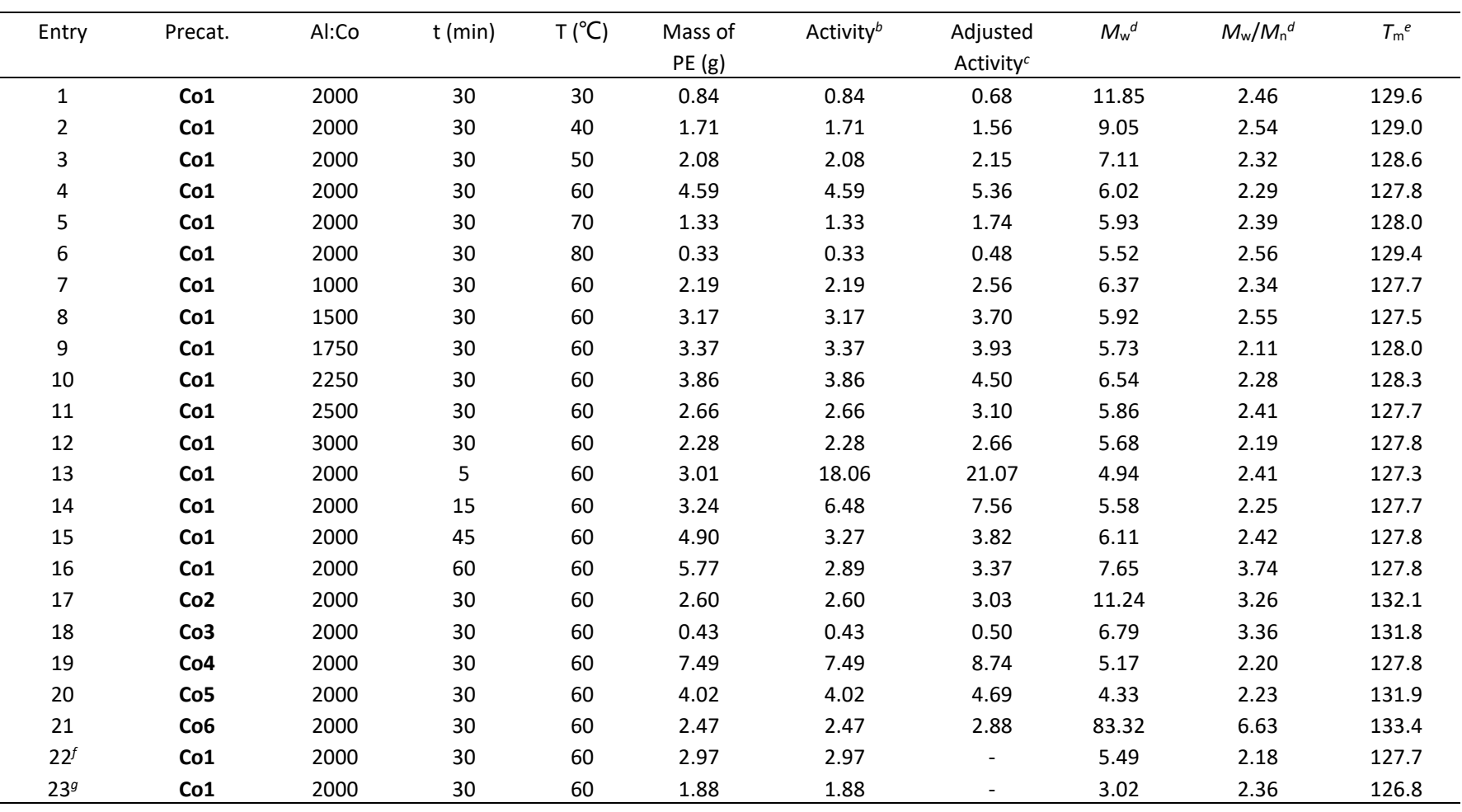

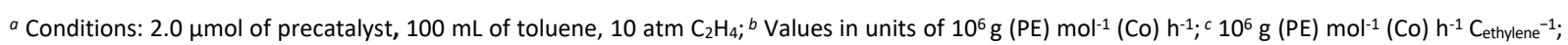

${ }^{d} M_{\mathrm{w}}: \mathrm{kg} \mathrm{mol}^{-1}$. $\mathrm{M}_{\mathrm{w}}$ and $\mathrm{M}_{\mathrm{w}} / \mathrm{M}_{\mathrm{n}}$ determined by GPC; ${ }^{e}$ Determined by DSC; $f 5$ atm $\mathrm{C}_{2} \mathrm{H}_{4} ;{ }^{g} 1$ atm $\mathrm{C}_{2} \mathrm{H}_{4}$

With regard to the effect of time on catalytic performance, the best activity for Co1/MMAO of $18.06 \times 10^{6} \mathrm{~g} \mathrm{PE} \mathrm{mol}^{-1}$ (Co) $\mathrm{h}^{-1}$ was observed after $5 \mathrm{~min}$ (entries 4 and $13-16$, Table 3 ), which compares to $24.12 \times 10^{6} \mathrm{~g} \mathrm{PE} \mathrm{mol}^{-1}$ (Co) $\mathrm{h}^{-1}$ for Co1/MAO at the $5 \mathrm{~min}$ mark. Indeed, the activity of Co1/MMAO was almost four times that achieved after $30 \mathrm{~min}$ (entry 4, Table 3), which highlights both the rate at which the active species was generated after MMAO addition and its rapid deactivation. ${ }^{30,33,46}$ However, on prolonging the reaction time beyond $30 \mathrm{~min}$, the activity gradually decreased reaching its lowest value of $2.89 \times 10^{6} \mathrm{~g} \mathrm{PE} \mathrm{mol}^{-1}$ (Co) h-1 after $60 \mathrm{~min}$. As expected, the molecular weights of the polyethylenes increased with longer reaction time reaching their maximum value of $7.65 \mathrm{~kg} \mathrm{~mol}^{-1}$ after $60 \mathrm{~min}$ (see Figures S37 - S40).

Similar to the Co1/MAO study, a reduction in the ethylene pressure from 10 to $1 \mathrm{~atm}$ led to a decrease in the activity for Co1/MMAO though the range in values in this case is less pronounced (from 4.59 to $1.88 \times 10^{6} \mathrm{~g} \mathrm{PE} \mathrm{mol}^{-1}$ (Co) $\mathrm{h}^{-1}$; entries 4, 22, 23, Table 3). Conversely, the trend in molecular weight of the polymers (see Figures S46 - S47) is now clearer with the values steadily decreasing as the pressure was reduced from 10 to $1 \mathrm{~atm}$ reaching a minimum value of $3.0 \mathrm{~kg}$ $\mathrm{mol}^{-1}$ at the lowest pressure (entry 23 , Table 3 ).

Under the favored operating conditions established for Co1/MMAO, the influence of ligand structure on the performance of the cobalt catalyst was explored by investigating the remaining precatalysts Co2 - Co6. All the cobalt precatalysts exhibited high activity toward ethylene polymerization. In comparison with the catalytic performance with MAO as co-catalyst (entries 5 and $18-22$, Table 2), Co1 Co6/MMAO (entries 4 and $17-21$, Table 3 ) exhibited slightly lower activities [range with MAO: $11.9-0.51 \mathrm{~g} \mathrm{PE} \mathrm{mol}^{-1}$ (Co) $\mathrm{h}^{-1}$ vs. MMAO: $7.59-0.43 \mathrm{~g}^{\mathrm{PE}} \mathrm{mol}^{-1}$ (Co) $\mathrm{h}^{-1}$ ]. Even so, a similar trend in performance was observed: Co4 (2,4,6trimethyl) > Co1 (2,6-dimethyl) > Co5 (2,6-diethyl-4-methyl) > $\operatorname{Co2}$ (2,6-diethyl) > Co6 (2,4,6-t-butyl) > Co3 (2,6-diisopropyl). Hence, related steric/electronic arguments can be used to account for the performance variations. Once again, the most sterically hindered system, Co6 (2,4,6-t-butyl), produced polyethylene with the highest molecular weight $(83.32 \mathrm{~kg}$ $\mathrm{mol}^{-1}$, entry 21 , Table 3 ) which is appreciably higher than that seen with other substitution patterns (4.33 to $11.24 \mathrm{~kg}$ 
$\left.\mathrm{mol}^{-1}\right) \cdot{ }^{19,30,33-35}$ Moreover, all the cobalt complexes formed polyethylenes exhibiting mostly narrow polydispersities ( $M_{\mathrm{w}} / M_{\mathrm{n}}$ range: $2.1-6.6$, see Figures $\mathrm{S41}-\mathrm{S} 45$ ), similar findings have been reported for cobalt containing $A,{ }^{3} C^{30} \mathbf{D}^{32}$ and $\mathbf{E}^{33,35}$ (Chart 1).

To allow a comparison of the performance of Co4 with structurally related $\mathbf{C}^{30} \mathbf{D},{ }^{32}$ and $\mathbf{E},{ }^{33,35}$ various polymer properties as well as catalytic activities are collected in Chart 2. Under comparable polymerization conditions (namely MAO as co-catalyst and 10 atm ethylene), Co4 exhibited the highest catalytic activity and thermal stability of the series, indicating that the two methyl substituents located at the C-7 position of the fused ring have a beneficial effect on performance. With regard to the properties of the polyethylenes obtained, Co4 produced narrowly dispersed polyethylene waxes with molecular weights in the thousands that are indeed of higher molecular weight when compared with its unsubstituted mesityl-containing comparator $\mathbf{C}$. It is noteworthy, that such linear polyethylene waxes are attracting interest due to, among other things, their use as new comonomers for long chain branched polymers and coating materials. ${ }^{26}$

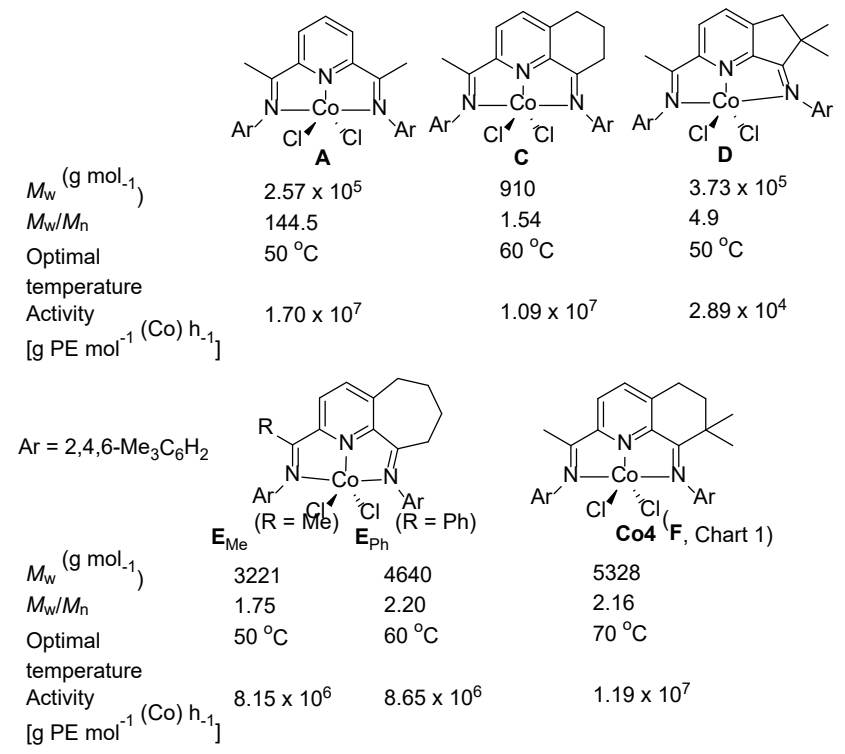

Chart 2 Comparison of the $M_{\mathrm{w}}, M_{\mathrm{w}} / M_{\mathrm{n}}$, optimal temperature and activity for $\mathrm{A}, \mathrm{C}-\mathbf{E}$ $\left(\mathrm{Ar}=2,4,6-\mathrm{Me}_{3} \mathrm{C}_{6} \mathrm{H}_{2}\right)$ with the corresponding data obtained for $\mathrm{Co} 4(\mathbf{F}$, Chart 1); in all cases MAO employed as activator under $10 \mathrm{~atm} \mathrm{C}_{2} \mathrm{H}_{4}$.

\section{Microstructural properties of the polyethylenes}

As a common feature to both co-catalyst investigations, the melt temperatures of the polymers fall in the range 127.3 $132.1{ }^{\circ} \mathrm{C}$ which are quite typical of highly linear materials. ${ }^{16-19}$ To confirm this supposition and to gain some information as to the end group composition and likely termination mechanisms, representative polymer samples prepared using Co1 with either MAO or MMAO have been the subject of high temperature ${ }^{1} \mathrm{H}$ and ${ }^{13} \mathrm{C}$ NMR spectroscopy. ${ }^{49-51}$ Firstly, the ${ }^{1 \mathrm{H}}$ NMR spectrum of the polymer obtained using Co1/MAO at 70 ${ }^{\circ} \mathrm{C}$ (entry 5 , Table 2 ) was recorded revealing an intense signal at $\delta 1.36$ assignable to the $-\left(\mathrm{CH}_{2}\right)_{n}$ - repeat unit in a linear polymer. In addition, weaker resonances attributable to a vinyl end group $\left(-\mathrm{CH}=\mathrm{CH}_{2}\right)$ could be seen as multiplets centered around $\delta 5.90$ and 5.00, while a more upfield signal at $\delta 0.98$ can be ascribed to a methyl chain end (Figure 5). The ratio of the integrals for these end groups (methyl:vinyl $=5.6: 3.0$ ) shows a bias towards methyl chain ends which is consistent with chain transfer to aluminum operating alongside $\beta-\mathrm{H}$ elimination during chain termination. In the ${ }^{13} \mathrm{C} N M R$ spectrum, the low intensity signals at $\delta 139.49$ and $\delta 114.34$ were attributed to the vinylic carbons belonging to the unsaturated chain ends $\left(-\mathrm{CH}=\mathrm{CH}_{2}\right)$, while those more upfield at 33.99, 22.92 and 18.77 (I - III, Figure 6) to an n-propyl end group.

Secondly, a sample of the polyethylene obtained using Co1/MMAO at $60{ }^{\circ} \mathrm{C}$ (entry 4, Table 3 ) was also examined using high temperature ${ }^{1} \mathrm{H}$ and ${ }^{13} \mathrm{C}$ NMR spectroscopy (Figures 7 and 8). On the basis of the chemical shifts, similar assignments can be made in terms of end group composition. In this case, however, the methyl:vinyl chain end ratio (6.4:3.0), as shown in the ${ }^{1} \mathrm{H}$ NMR spectrum, shows a stronger bias towards methyl chain ends. Hence, it is apparent that chain transfer to trimethylaluminum and its derivatives in MMAO is more significant than seen with MAO;14,36 the effect of temperature on the chain transfer pathway cannot, however, be ruled out. By contrast, there is no evidence for peaks in the ${ }^{13} \mathrm{C}$ NMR spectrum corresponding to isobutyl end groups, precluding chain transfer to $\mathrm{Al}(i-\mathrm{Bu})_{3}$ and related species in MMAO.

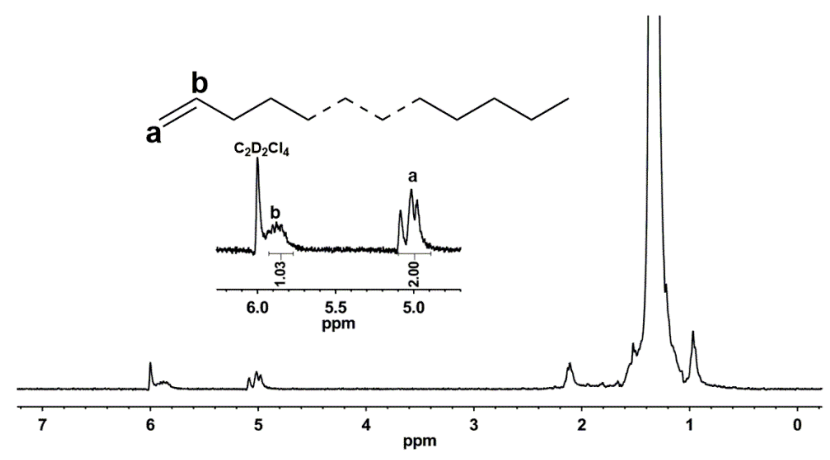

Figure $5^{1} \mathrm{H}$ NMR spectrum of the polyethylene obtained using Co1/MAO at $70^{\circ} \mathrm{C}$ (entry 5 , Table 2); recorded in deuterated 1,1,2,2-tetrachloroethane at $100^{\circ} \mathrm{C}$.

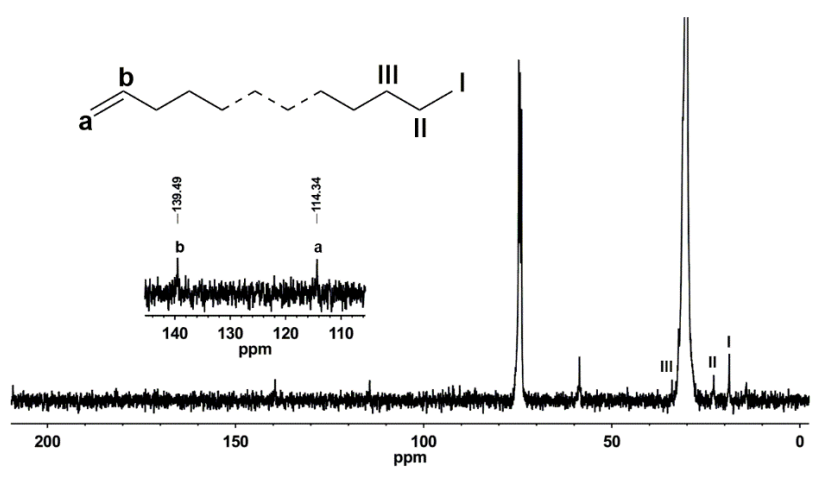

Figure $6{ }^{13} \mathrm{C}$ NMR spectrum of the polyethylene obtained using Co1/MAO at $70{ }^{\circ} \mathrm{C}$ (entry 5, Table 2); recorded in deuterated 1,1,2,2-tetrachloroethane at $100^{\circ} \mathrm{C}$. 


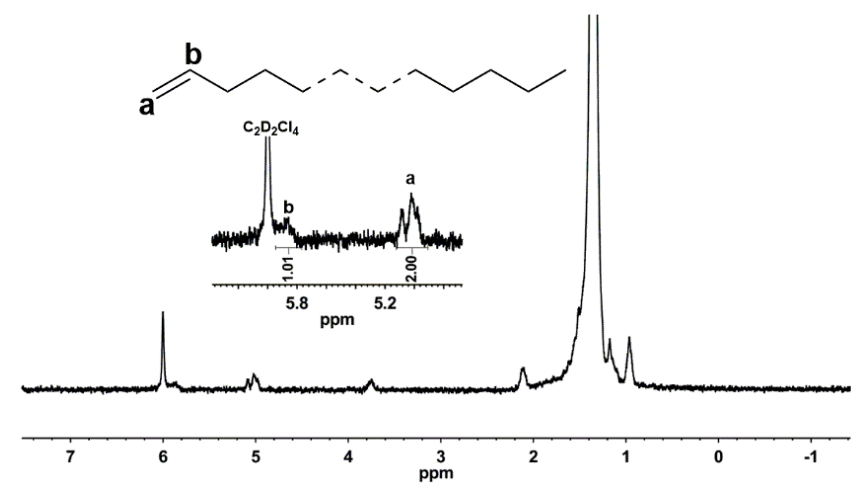

Figure $7{ }^{1} \mathrm{H}$ NMR spectrum of the polyethylene obtained using Co1/MMAO at $60{ }^{\circ} \mathrm{C}$ (entry 4, Table 3); recorded in deuterated 1,1,2,2-tetrachloroethane at $100^{\circ} \mathrm{C}$.

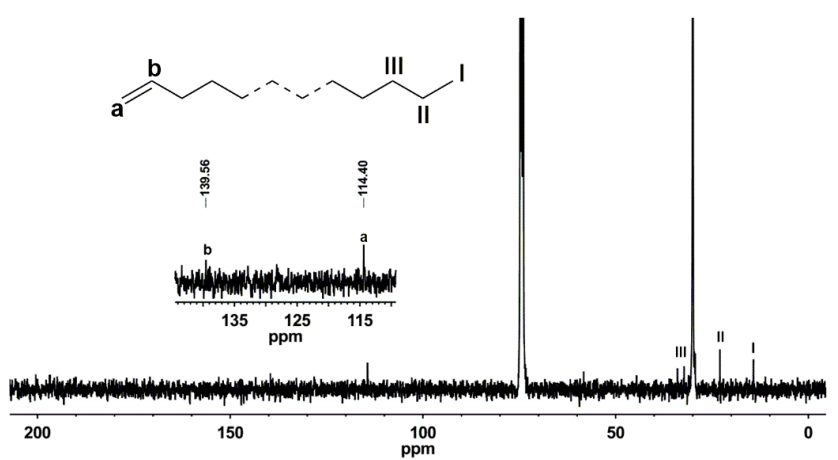

Figure $8{ }^{13} \mathrm{C}$ NMR spectrum of the polyethylene obtained using Co1/MMAO at $60{ }^{\circ} \mathrm{C}$ (entry 4, Table 3); recorded in deuterated 1,1,2,2-tetrachloroethane at $100^{\circ} \mathrm{C}$

\section{Conclusions}

In summary, six examples of bis(imino)-7,7-dimethyl-5,6dihydroquinoline-cobalt(II) chlorides (Co1 - Co6) have been successfully synthesized and characterized, including in two cases by single crystal X-ray diffraction. All the title cobalt precatalysts, on treatment with MAO and MMAO, exhibited very high activities for ethylene polymerization with mesitylcontaining Co4/MAO being the most active and what is more achieving this level at $70{ }^{\circ} \mathrm{C}\left(1.19 \times 10^{7} \mathrm{~g} \mathrm{PE} \mathrm{mol}^{-1}(\mathrm{Co}) \mathrm{h}^{-1}\right)$. Indeed, this thermal stability exceeds that displayed by its unsubstituted counterpart $\mathbf{C}$ highlighting the positive effects of gem-dimethyl substitution. Moreover, this class of catalyst shows a good catalytic lifetime that following an initial spike in activity maintained a relatively stable profile even after one hour. The polyethylenes obtained using Co1 - Co5 displayed low molecular weight $\left(M_{\mathrm{w}}\right.$ : ranging from 9 to $\left.16 \mathrm{~kg} \mathrm{~mol}^{-1}\right)$ and narrow dispersity suggestive of a single-site active species. Furthermore, chain end analysis reveals appreciable levels of vinyl groups. It is noteworthy that such linear polyethylene waxes are in high demand for a variety of industrial applications and hence the cobalt catalysts developed herein show great promise in this area.

\section{Experimental}

\section{General Considerations}

All the manipulations of air- and/or moisture-sensitive operations were undertaken under a nitrogen atmosphere using standard Schlenk techniques. Toluene was refluxed over sodium and distilled under nitrogen prior to use. Methylaluminoxane (1.46 M solution in toluene) and modified methylaluminoxane (MMAO, $1.93 \mathrm{M}$ in $n$-heptane) were purchased from Akzo Nobel Corp. High-purity ethylene was purchased from Beijing Yanshan Petrochemical Co. and used as received. Other reagents were purchased from Aldrich, Acros or local suppliers. 2-Acetyl-7,7-dimethyl-5,6-dihydroquinolin-8one was prepared based on procedure described in the literature. ${ }^{37}$ NMR spectra were recorded on a Bruker DMX 400 $\mathrm{MHz}$ instrument at ambient temperature using TMS as an internal standard. The ${ }^{1} \mathrm{H}$ and ${ }^{13} \mathrm{C}$ NMR spectra of the polyethylenes were recorded on a Bruker DMX $300 \mathrm{MHz}$ instrument at $100{ }^{\circ} \mathrm{C}$ in deuterated 1,1,2,2-tetrachloroethane with TMS as an internal standard. IR spectra were recorded on a Perkin-Elmer System 2000 FTIR spectrometer. Elemental analysis was carried out using a Flash EA 1112 microanalyzer. Molecular weights and molecular weight distributions $\left(M_{\mathrm{w}} / M_{\mathrm{n}}\right)$ of the polyethylenes were determined by a PL-GPC220 at 150 ${ }^{\circ} \mathrm{C}$ with 1,2,4-trichlorobenzene as the solvent. Data collection and handling were carried out using Cirrus GPC Software (Beijing, China) and Multi Detector Software (Beijing, China). The calibrants employed for constructing conventional calibration were Polystyrene Calibration KitS-M-10 from PL Company (Beijing, China). The true average molecular weights of the PEs were determined by inputting the Mark-Houwink constants of PE; $K$ of 0.727 and of 40.6 are provided by $P L$ Company (Beijing, China). Samples were dissolved at a concentration of 1.0 to $2.5 \mathrm{mg} \mathrm{mL}^{-1}$, depending on the molecular weights. The DSC traces and melting temperatures of the polyethylenes were obtained from the second scanning run on DSC Q2000 instrument at a heating rate of $10^{\circ} \mathrm{C} \mathrm{min}-1$ to $160^{\circ} \mathrm{C}$.

\section{Synthesis of $2-(\mathrm{ArN}=\mathrm{CMe})-8-(\mathrm{ArN})-7,7-\mathrm{Me}_{2} \mathrm{C}_{9} \mathrm{H}_{6} \mathrm{~N}$}

(a) $\mathrm{Ar}=$ 2,6- $\mathrm{Me}_{2} \mathrm{C}_{6} \mathrm{H}_{3}$ L1. 2,6-Dimethylaniline (0.60 mg, 5.0 $\mathrm{mmol}$ ) was added to a solution of 1,2-dichlorobenzene $(30 \mathrm{~mL})$ containing 2-acetyl-7,7-dimethyl-5,6-dihydroquinolin-8-one $(0.43 \mathrm{~g}, 2.0 \mathrm{mmol})$ and a catalytic amount of $p$-toluene sulfonic acid $(c a .0 .04 \mathrm{~g}$ ). The mixture was then stirred at reflux for $4 \mathrm{~h}$. Once cooled to room temperature, the solvent was evaporated under reduced pressure and the residue purified by silica gel chromatography using petroleum ether/ethyl acetate $(\mathrm{v} / \mathrm{V}=50: 3)$ as eluent to afford $\mathbf{L} 1$ as a yellow oil $(0.18$ g, 22\%). ${ }^{1} \mathrm{H}$ NMR (400 MHz, $\mathrm{CDCl}_{3}$ ): $\delta 8.14(\mathrm{~d}, J=7.8 \mathrm{~Hz}, 1 \mathrm{H}$, Py), $7.61(\mathrm{~d}, J=8.1 \mathrm{~Hz}, 1 \mathrm{H}, \mathrm{Py}), 7.00(\mathrm{~d}, J=7.5 \mathrm{~Hz}, 2 \mathrm{H}, \mathrm{Ph}), 6.87$ $(\mathrm{t}, J=9.1 \mathrm{~Hz}, 3 \mathrm{H}, \mathrm{Ph}), 6.63(\mathrm{t}, J=7.5 \mathrm{~Hz}, 1 \mathrm{H}, \mathrm{Ph}), 3.03(\mathrm{t}, J=6.3$ $\left.\mathrm{Hz}, 2 \mathrm{H},-\mathrm{CH}_{2}-\right), 2.06\left(\mathrm{t}, J=6.3 \mathrm{~Hz}, 2 \mathrm{H},-\mathrm{CH}_{2}-\right), 1.89(\mathrm{~s}, 12 \mathrm{H}, 4 \times-$ $\left.\mathrm{CH}_{3}\right), 1.44\left(\mathrm{~s}, 6 \mathrm{H}, 2 \times-\mathrm{CH}_{3}\right), 1.27\left(\mathrm{~s}, 3 \mathrm{H},-\mathrm{CH}_{3}\right) .{ }^{13} \mathrm{C} \mathrm{NMR}(100$ $\left.\mathrm{MHz}_{1} \mathrm{CDCl}_{3}, \mathrm{TMS}\right): \delta 167.9,166.5,154.1,151.0,148.7,146.1$, $137.5,136.8,127.7,127.5,125.5,122.9,122.8,121.4,120.6$, 40.1, 36.6, 26.7, 25.6, 18.1, 17.8, 15.8. FT-IR $\left(\mathrm{KBr} \mathrm{cm}^{-1}\right): 2958$ $(w), 2866(w), 1652\left(u_{C=N}, m\right), 1458(w), 1430(w), 1369(w)$, 1343 (w), 1295 (w), 1259 (m), 1239 (w), 1200 (w), 1137 (w), $1082(w), 1016(m), 922$ (w), 861 (w), 795 (s), 755 (w). Anal. 
calcd for $\mathrm{C}_{29} \mathrm{H}_{33} \mathrm{~N}_{3}$ (423.27): C, 82.23; $\mathrm{H}, 7.85 ; \mathrm{N}, 9.92$. Found: C, 82.53; $\mathrm{H}, 7.69 ; \mathrm{N}, 9.99 \%$.

(b) $\mathrm{Ar}=2,6-E t_{2} \mathrm{C}_{6} \mathrm{H}_{3} \mathbf{L 2}$. By using the same procedure and molar ratios as described for the synthesis of $\mathbf{L 1}, \mathbf{L 2}$ was obtained as a yellow oil (0.32 g, 33\%). ${ }^{1} \mathrm{H} \mathrm{NMR}\left(400 \mathrm{MHz} \mathrm{CDCl}_{3}\right): \delta 8.11(\mathrm{~d}, J$ $=8.0 \mathrm{~Hz}, 1 \mathrm{H}, \mathrm{Py}), 7.61(\mathrm{~d}, J=8.0 \mathrm{~Hz}, 1 \mathrm{H}, \mathrm{Py}), 7.05(\mathrm{~d}, J=7.6 \mathrm{~Hz}$, $2 \mathrm{H}, \mathrm{Ph}), 7.00-6.96(\mathrm{t}, J=7.6 \mathrm{~Hz}, 1 \mathrm{H}, \mathrm{Ph}), 6.91(\mathrm{~d}, J=7.6 \mathrm{~Hz}, 2 \mathrm{H}$, $\mathrm{Ph}), 6.72(\mathrm{t}, J=7.4 \mathrm{~Hz}, 1 \mathrm{H}, \mathrm{Ph}), 3.04\left(\mathrm{t}, J=6.4 \mathrm{~Hz}, 2 \mathrm{H},-\mathrm{CH}_{2}-\right)$, 2.39-2.29 (m, $\left.2 \mathrm{H},-\mathrm{CH}_{2}-\right), 2.28-2.16\left(\mathrm{~m}, 6 \mathrm{H}, 3 \times-\mathrm{CH}_{2}-\right), 2.08(\mathrm{t}, J$ $\left.=6.4 \mathrm{~Hz}, 2 \mathrm{H},-\mathrm{CH}_{2}-\right), 1.45\left(\mathrm{~s}, 6 \mathrm{H}, 2 \times-\mathrm{CH}_{3}\right), 1.24\left(\mathrm{~s}, 3 \mathrm{H},-\mathrm{CH}_{3}\right)$, $1.06\left(\mathrm{t}, J=7.6 \mathrm{~Hz}, 6 \mathrm{H}, 2 \times-\mathrm{CH}_{3}\right), 1.00(\mathrm{t}, J=7.6 \mathrm{~Hz}, 6 \mathrm{H}, 2 \times-$ $\left.\mathrm{CH}_{3}\right) .{ }^{13} \mathrm{C} \mathrm{NMR}\left(100 \mathrm{MHz}, \mathrm{CDCl}_{3}, \mathrm{TMS}\right): \delta 168.0,165.8,154.3$, $150.3,147.9,145.9,137.8,137.2,131.4,128.3,126.0,125.6$, 123.2, 121.5, 121.0, 40.3, 36.7, 26.7, 25.8, 24.7, 24.6, 16.4, 13.8, 13.4. FT-IR ( $\left.\mathrm{KBr} \mathrm{cm}^{-1}\right)$ : 2974 (w), 2927 (w), 2875 (w), 1643 $\left(u_{\mathrm{C}=\mathrm{N}}, \mathrm{m}\right), 1587(\mathrm{w}), 1560(\mathrm{w}), 1445(\mathrm{~s}), 1395(\mathrm{w}), 1368(\mathrm{~m})$, $1343(w), 1293(w), 1232(w), 1198(m), 1161(w), 1123(w)$, $1029(w), 1000(w), 960(w), 906(w), 872(w), 857(w), 779(w)$, 755 (s), 733 (w). Anal. calcd for $\mathrm{C}_{33} \mathrm{H}_{41} \mathrm{~N}_{3}$ (479.71): C, 82.63; $\mathrm{H}$, 8.62; N, 8.76. Found: $\mathrm{C}, 82.56 ; \mathrm{H}, 8.65 ; \mathrm{N}, 8.51 \%$.

(c) $\mathrm{Ar}=2,6-{ }^{i} \mathrm{Pr}_{2} \mathrm{C}_{6} \mathrm{H}_{3}$ L3. By using the same procedure and molar ratios as described for the synthesis of $\mathbf{L 1}, \mathbf{L} \mathbf{3}$ was obtained as a yellow oil (0.35 g, 33\%). ${ }^{1} \mathrm{H}$ NMR (400 MHz, $\left.\mathrm{CDCl}_{3}\right): \delta 8.11(\mathrm{~d}, J$ $=8.0 \mathrm{~Hz}, 1 \mathrm{H}, \mathrm{Py}), 7.62(\mathrm{~d}, J=8.0 \mathrm{~Hz}, 1 \mathrm{H}, \mathrm{Py}), 7.10(\mathrm{~d}, J=7.2 \mathrm{~Hz}$, $2 \mathrm{H}, \mathrm{Ph}), 7.05-7.01(\mathrm{~m}, 1 \mathrm{H}, \mathrm{Ph}), 6.97(\mathrm{~d}, J=7.6 \mathrm{~Hz}, 2 \mathrm{H}, \mathrm{Ph}), 6.76$ $(\mathrm{t}, J=7.6 \mathrm{~Hz}, 1 \mathrm{H}, \mathrm{Ph}), 3.05\left(\mathrm{t}, J=6.4 \mathrm{~Hz}, 2 \mathrm{H},-\mathrm{CH}_{2^{-}}\right), 2.71-2.64$ (m, $2 \mathrm{H}, 2 \times-\mathrm{CH}), 2.58-2.51(\mathrm{~m}, 2 \mathrm{H}, 2 \times-\mathrm{CH}), 2.08(\mathrm{t}, J=6.4 \mathrm{~Hz}$, $\left.2 \mathrm{H},-\mathrm{CH}_{2}-\right), 1.45\left(\mathrm{~s}, 6 \mathrm{H}, 2 \times-\mathrm{CH}_{3}\right), 1.18\left(\mathrm{~s}, 3 \mathrm{H},-\mathrm{CH}_{3}\right), 1.16(\mathrm{t}, J=$ $\left.6.8 \mathrm{~Hz}, 6 \mathrm{H}, 2 \times-\mathrm{CH}_{3}\right), 1.07$ (dd, $\left.J=7.2 \mathrm{~Hz}, 12 \mathrm{H}, 4 \times-\mathrm{CH}_{3}\right), 0.79$ (d, $\left.J=6.8 \mathrm{~Hz}, 6 \mathrm{H}, 2 \times-\mathrm{CH}_{3}\right) .{ }^{13} \mathrm{C}$ NMR $\left(100 \mathrm{MHz}, \mathrm{CDCl}_{3}, \mathrm{TMS}\right): \delta$ $168.1,165.4,154.2,149.2,146.6,145.7,137.9,137.5,135.9$, $132.5,123.5,123.0,122.7,121.5,121.2,40.4,36.7,28.3,28.2$, 26.7, 25.9, 23.2, 23.1, 23.0, 22.5, 16.7. FT-IR ( $\left.\mathrm{KBr} \mathrm{cm}{ }^{-1}\right): 2958$ $(s), 2925(w), 2865(w), 1648\left(u_{C=N}, s\right), 1587(w), 1553(w), 1461$ (s), $1429(\mathrm{~m}), 1381(w), 1333(w), 1248(w), 1221(w), 1185(w)$, $1156(w), 1114(s), 1049(m), 1010(w), 936(w), 877(w), 838$ (w), $767(\mathrm{~m}), 747$ (m). Anal. calcd for $\mathrm{C}_{37} \mathrm{H}_{49} \mathrm{~N}_{3}$ (535.82): C, 82.94; $\mathrm{H}, 9.22 ; \mathrm{N}, 7.84$. Found: $\mathrm{C}, 82.57 ; \mathrm{H}, 9.04 ; \mathrm{N}, 7.48 \%$.

(d) $\mathrm{Ar}=2,4,6-\mathrm{Me}_{3} \mathrm{C}_{6} \mathrm{H}_{2}$ L4. By using the same procedure and molar ratios as described for the synthesis of L1, L4 was obtained as a yellow oil (0.06 g, 13\%). ${ }^{1} \mathrm{H}$ NMR $(400 \mathrm{MHz}$, $\mathrm{CDCl}_{3}$ ): $\delta 8.10$ (d, $\left.J=10.8 \mathrm{~Hz}, 1 \mathrm{H}, \mathrm{Py}\right), 7.58(\mathrm{~d}, J=11.2 \mathrm{~Hz}, 1 \mathrm{H}$, $\mathrm{Py}), 6.84(\mathrm{~d}, J=8.0 \mathrm{~Hz}, 2 \mathrm{H}, \mathrm{Ph}), 6.65(\mathrm{~s}, 2 \mathrm{H}, \mathrm{Ph}), 3.00(\mathrm{t}, J=8.4$ $\left.\mathrm{Hz}, 2 \mathrm{H},-\mathrm{CH}_{2}-\right), 2.32\left(\mathrm{~s}, 3 \mathrm{H},-\mathrm{CH}_{3}\right), 2.11\left(\mathrm{~s}, 3 \mathrm{H},-\mathrm{CH}_{3}\right), 2.06-1.98$ $\left(\mathrm{m}, 4 \mathrm{H},-\mathrm{CH}_{2}-\right), 1.86\left(\mathrm{t}, J=9.8 \mathrm{~Hz}, 12 \mathrm{H}, 4 \times-\mathrm{CH}_{3}\right), 1.54(\mathrm{~s}, 6 \mathrm{H}, 2 \times$ $\left.-\mathrm{CH}_{3}\right), 1.41\left(\mathrm{~s}, 3 \mathrm{H},-\mathrm{CH}_{3}\right) .{ }^{13} \mathrm{C}$ NMR (100 MHz, $\left.\mathrm{CDCl}_{3}, \mathrm{TMS}\right): \delta$ $168.3,167.0,154.2,148.6,146.4,137.5,136.7,132.1,129.6$, $128.5,128.4,128.2,125.5,123.0,121.4,40.2,36.8,26.8,25.7$, 20.8, 20.7, 18.1, 17.8, 15.6. FT-IR ( $\left.\mathrm{KBr} \mathrm{cm} \mathrm{cm}^{-1}\right): 2961$ (w), 2919 $(m), 2855(w), 1649\left(u_{C=N}, s\right), 1600(w), 1473(m), 1444(w)$, $1363(w), 1324(w), 1269(w), 1233(w), 1213(w), 1140(w)$, $1118(w), 1051(w), 1008(w), 958(w), 849(s), 823(w), 747$ (w). Anal. calcd for $\mathrm{C}_{31} \mathrm{H}_{37} \mathrm{~N}_{3}$ (451.66): C, 82.44; $\mathrm{H}, 8.26 ; \mathrm{N}$, 9.30. Found: $\mathrm{C}, 82.13 ; \mathrm{H}, 8.04 ; \mathrm{N}, 8.95 \%$.

(e) $\mathrm{Ar}=2,6-\mathrm{Et}_{2}-4-\mathrm{MeC}_{6} \mathrm{H}_{2}$ L5. By using the same procedure and molar ratios as described for the synthesis of L1, $\mathbf{L 5}$ was obtained as a yellow oil $(0.14 \mathrm{~g}, 27 \%) .{ }^{1} \mathrm{H}$ NMR $(400 \mathrm{MHz}$
$\left.\mathrm{CDCl}_{3}\right): \delta 8.07(\mathrm{~d}, J=8.4 \mathrm{~Hz}, 1 \mathrm{H}, \mathrm{Py}), 7.59(\mathrm{~d}, J=8.0 \mathrm{~Hz}, 1 \mathrm{H}, \mathrm{Py})$, $6.86(\mathrm{~s}, 2 \mathrm{H}, \mathrm{Ph}), 6.70(\mathrm{~s}, 2 \mathrm{H}, \mathrm{Ph}), 3.02\left(\mathrm{t}, J=6.4 \mathrm{~Hz}, 2 \mathrm{H},-\mathrm{CH}_{2}-\right)$, $2.30\left(\mathrm{~s}, 3 \mathrm{H},-\mathrm{CH}_{3}\right), 2.29-2.24\left(\mathrm{~m}, 4 \mathrm{H}, 2 \times-\mathrm{CH}_{2}-\right), 2.23-2.16(\mathrm{~m}$, $\left.4 \mathrm{H}, 2 \times-\mathrm{CH}_{2}-\right), 2.14\left(\mathrm{~s}, 3 \mathrm{H},-\mathrm{CH}_{3}\right), 2.05\left(\mathrm{t}, J=6.6 \mathrm{~Hz}, 2 \mathrm{H},-\mathrm{CH}_{2}-\right)$, $1.42\left(\mathrm{~s}, 6 \mathrm{H}, 2 \times-\mathrm{CH}_{3}\right), 1.25\left(\mathrm{~s}, 3 \mathrm{H},-\mathrm{CH}_{3}\right), 1.03(\mathrm{t}, J=7.4 \mathrm{~Hz}, 6 \mathrm{H}, 2$ $\left.\times-\mathrm{CH}_{3}\right), 0.96\left(\mathrm{t}, J=7.6 \mathrm{~Hz}, 6 \mathrm{H}, 2 \times-\mathrm{CH}_{3}\right) .{ }^{13} \mathrm{C} \mathrm{NMR}(100 \mathrm{MHz}$, $\left.\mathrm{CDCl}_{3}, \mathrm{TMS}\right): \delta 168.3,166.1,154.3,147.8,146.0,145.4,137.6$, 137.0, 132.3, 131.4, 129.7, 128.3, 126.8, 126.3, 121.4, 40.3, 36.7, 26.7, 25.8, 24.7, 24.6, 21.1, 20.9, 16.1, 14.0, 13.5. FT-IR $\left(\mathrm{KBr} \mathrm{cm}{ }^{-1}\right)$ : $2960(\mathrm{w}), 2925(\mathrm{w}), 2862(\mathrm{w}), 1643\left(\mathrm{u}_{\mathrm{C}=\mathrm{N}}, \mathrm{s}\right), 1588$ $(w), 1550(w), 1456(s), 1363(w), 1307(w), 1284(w), 1258(w)$, $1232(w), 1209(w), 1148(w), 1116(m), 1084(w), 1007(w)$, $860(\mathrm{~m}), 836$ (w), $783(w)$. Anal. calcd for $\mathrm{C}_{35} \mathrm{H}_{45} \mathrm{~N}_{3}$ (535.82): C, 82.79; $\mathrm{H}, 8.93 ; \mathrm{N}, 8.28$. Found: $\mathrm{C}, 82.39 ; \mathrm{H}, 8.95 ; \mathrm{N}, 7.95 \%$.

(f) $\mathrm{Ar}=2,4,6-{ }^{t} \mathrm{Bu}_{3} \mathrm{C}_{6} \mathrm{H}_{2}$ L6. By using the same procedure and molar ratios as described for the synthesis of L1, L6 was obtained as a yellow oil $(0.18 \mathrm{~g}, 35 \%) .{ }^{1} \mathrm{H}$ NMR $(400 \mathrm{MHz}$, $\mathrm{CDCl}_{3}$ ): $\delta 8.07$ (d, $\left.J=8.4 \mathrm{~Hz}, 1 \mathrm{H}, \mathrm{Py}\right), 7.59$ (d, $J=8.0 \mathrm{~Hz}, 1 \mathrm{H}, \mathrm{Py}$ ), $7.31(\mathrm{~s}, 2 \mathrm{H}, \mathrm{Ph}), 6.83(\mathrm{~s}, 2 \mathrm{H}, \mathrm{Ph}), 3.02\left(\mathrm{t}, J=6.4 \mathrm{~Hz}, 2 \mathrm{H},-\mathrm{CH}_{2}-\right)$, $2.03\left(\mathrm{t}, J=6.6 \mathrm{~Hz}, 2 \mathrm{H},-\mathrm{CH}_{2}-\right), 1.57\left(\mathrm{~s}, 6 \mathrm{H}, 2 \times-\mathrm{CH}_{3}\right), 1.42(\mathrm{~s}, 9 \mathrm{H}$, $\left.3 \times-\mathrm{CH}_{3}\right), 1.36\left(\mathrm{~s}, 9 \mathrm{H}, 3 \times-\mathrm{CH}_{3}\right), 1.34\left(\mathrm{~s}, 9 \mathrm{H}, 3 \times-\mathrm{CH}_{3}\right), 1.31(\mathrm{~s}$, $\left.9 \mathrm{H}, 3 \times-\mathrm{CH}_{3}\right), 1.28\left(\mathrm{~d}, J=7.6 \mathrm{~Hz}, 3 \mathrm{H},-\mathrm{CH}_{3}\right), 1.25(\mathrm{~s}, 9 \mathrm{H}, 3 \times-$ $\left.\mathrm{CH}_{3}\right), 1.21\left(\mathrm{~s}, 9 \mathrm{H}, 3 \times-\mathrm{CH}_{3}\right) .{ }^{13} \mathrm{C}$ NMR $\left(100 \mathrm{MHz} \mathrm{CDCl}_{3}, \mathrm{TMS}\right): \delta$ $165.5,164.3,153.8,149.9,146.8,145.8,143.7,138.8,137.3$, $130.5,127.7,123.1,122.8,122.4,120.9,39.9,36.3,35.6,35.2$, 34.9, 34.4, 34.2, 31.5, 29.6, 29.5, 25.5, 16.2. FT-IR $\left(\mathrm{KBr} \mathrm{cm}{ }^{-1}\right)$ : $2956(\mathrm{~s}), 2928(w), 2867(w), 1636\left(u_{C=N}, m\right), 1602(w), 1560$ $(w), 1487(m), 1459(m), 1393(w), 1361(m), 1262(w), 1238$ $(m), 1203(w), 1116(w), 1088(w), 1050(w), 1023(w), 932(w)$, 879 (w), 807 (m), 700 (w). Anal. calcd for $\mathrm{C}_{49} \mathrm{H}_{73} \mathrm{~N}_{3}$ (704.14): C, 83.58; $\mathrm{H}, 10.45 ; \mathrm{N}, 5.97$. Found: $\mathrm{C}, 83.23 ; \mathrm{H}, 10.14 ; \mathrm{N}, 5.95 \%$.

\section{Synthesis of [2-(ArN=CMe)-8-(ArN)-7,7- $\left.\mathrm{Me}_{2} \mathrm{C}_{9} \mathrm{H}_{6} \mathrm{~N}\right] \mathrm{CoCl}_{2}$}

(a) $\mathrm{Ar}=2,6-\mathrm{Me}_{2} \mathrm{C}_{6} \mathrm{H}_{3} \mathrm{Co1}$. Under a nitrogen atmosphere, L1 $(0.18 \mathrm{~g}, 0.43 \mathrm{mmol})$ and $\mathrm{CoCl}_{2}(0.06 \mathrm{~g}, 0.43 \mathrm{mmol})$ were added to a mixture of dichloromethane $(15 \mathrm{~mL})$ and ethanol $(5 \mathrm{~mL})$ and the resulting solution stirred at room temperature. After $24 \mathrm{~h}$, all volatiles were evaporated under reduced pressure to give a concentrated solution. An excess of diethyl ether was added to induce precipitation and the solid collected by filtration, washed with diethyl ether $(3 \times 10 \mathrm{~mL})$ and dried under reduced pressure to give Co1 as a brown powder (0.20 g, 84\%). FT-IR ( $\left.\mathrm{KBr} \mathrm{cm}^{-1}\right): 2962(\mathrm{w}), 2873(\mathrm{w}), 1612\left(u_{\mathrm{C}=\mathrm{N}}, \mathrm{w}\right)$, $1578(w), 1560(w), 1456(m), 1421(m), 1373(w), 1305(w)$, $1278(w), 1221(m), 1199(m), 1166(w), 1132(w), 1093(w)$, $968(w), 837(m), 786(w), 767(m)$. Anal. calcd for $\mathrm{C}_{29} \mathrm{H}_{33} \mathrm{Cl}_{2} \mathrm{CoN}_{3}$ (553.44): C, 62.94; $\mathrm{H}, 6.01 ; \mathrm{N}, 7.59$. Found: $\mathrm{C}$, 62.60; $\mathrm{H}, 5.88 ; \mathrm{N}, 7.23 \%$.

(b) $\mathrm{Ar}=2,6-\mathrm{Et}_{2} \mathrm{C}_{6} \mathrm{H}_{3} \mathrm{Co2}$. By using a procedure similar to that described for Co1, Co2 was isolated as a brown powder (0.24 g, 59\%). FT-IR $\left(\mathrm{KBr} \mathrm{cm}^{-1}\right)$ : $2967(\mathrm{w}), 2875(\mathrm{w}), 1612\left(u_{\mathrm{C}=\mathrm{N}}, \mathrm{w}\right)$, $1580(w), 1541(w), 1451(m), 1399(w), 1371(w), 1312(w)$, $1282(w), 1229(m), 1193(\mathrm{~m}), 1168(w), 1133(w), 1069(w)$, $959(w), 844(m), 804(w), 769$ (w). Anal. calcd for $\mathrm{C}_{33} \mathrm{H}_{41} \mathrm{Cl}_{2} \mathrm{CoN}_{3}$ (609.55): C, 65.03; $\mathrm{H}, 6.78 ; \mathrm{N}, 6.89$. Found: $\mathrm{C}$, $64.72 ; \mathrm{H}, 6.47 ; \mathrm{N}, 6.83 \%$. 
(c) $\mathrm{Ar}=2,6^{-}{ }^{i} \mathrm{Pr}_{2} \mathrm{C}_{6} \mathrm{H}_{3} \mathrm{Co}$. By using a procedure similar to that described for Co1, Co3 was isolated as a brown powder $(0.28$ g, 65\%). FT-IR ( $\left.\mathrm{KBr} \mathrm{cm}{ }^{-1}\right): 2961(\mathrm{w}), 2873(\mathrm{w}), 1612\left(u_{\mathrm{C}=\mathrm{N}}, \mathrm{w}\right)$, $1581(w), 1508$ (w), $1466(m), 1437$ (w), $1393(w), 1366(w)$, $1331(w), 1225(m), 1196(m), 1177(w), 1139(w), 1099(w)$ $917(w), 844(w), 797(m), 772$ (w). Anal. calcd for $\mathrm{C}_{37} \mathrm{H}_{49} \mathrm{Cl}_{2} \mathrm{CON}_{3}$ (665.65): C, 66.76; $\mathrm{H}, 7.42 ; \mathrm{N}, 6.31$. Found: $\mathrm{C}$, $66.42 ; \mathrm{H}, 7.11 ; \mathrm{N}, 6.11 \%$.

(d) $\mathrm{Ar}=2,4,6-\mathrm{Me}_{3} \mathrm{C}_{6} \mathrm{H}_{2} \mathrm{Co}$. By using a procedure similar to that described for Co1, Co4 was isolated as a brown powder (0.06 g, 72\%). FT-IR ( $\left.\mathrm{KBr} \mathrm{cm}^{-1}\right)$ : $2975(\mathrm{w}), 2852(\mathrm{w}), 1616\left(u_{\mathrm{C}=\mathrm{N}}\right.$, w), $1587(w), 1541(w), 1479(m), 1461(w), 1373(w), 1309(w)$, $1280(w), 1234(w), 1208(m), 1155(w), 1126(w), 1066(w)$, $958(w), 857(m), 810(w), 731(w)$. Anal. calcd for $\mathrm{C}_{31} \mathrm{H}_{37} \mathrm{Cl}_{2} \mathrm{CoN}_{3}$ (581.49): C, 64.03; $\mathrm{H}, 6.41 ; \mathrm{N}, 7.23$. Found: $\mathrm{C}$, 63,$73 ; \mathrm{H}, 6.07 ; \mathrm{N}, 6.87 \%$.

(e) $\mathrm{Ar}=2,6-\mathrm{Et}_{2}-4-\mathrm{MeC}_{6} \mathrm{H}_{2}$ Co5. By using a procedure similar to that described for Co1, Co5 was isolated as a brown powder (0.03 g, 60\%). Co1 as a brown powder (0.20 g, 84\%). FT-IR ( $\mathrm{KBr}$ $\left.\mathrm{cm}^{-1}\right)$ : $2969(w), 2878(w), 1618\left(u_{\mathrm{C}=\mathrm{N}}, w\right), 1588(w), 1559(w)$, $1457(m), 1373(w), 1338(w), 1314(w), 1281(w), 1227(w)$, $1203(\mathrm{~m}), 1124(w), 1071(w), 958(w), 859(m), 790(w)$. Anal. calcd for $\mathrm{C}_{35} \mathrm{H}_{45} \mathrm{Cl}_{2} \mathrm{CoN}_{3}$ (581.49): C, 65.93; $\mathrm{H}, 7.11 ; \mathrm{N}, 6.59$. Found: $\mathrm{C}, 65.56 ; \mathrm{H}, 7.00 ; \mathrm{N}, 6.46 \%$.

(f) $\mathrm{Ar}=2,4,6^{-}{ }^{\mathrm{B}} \mathrm{Bu} \mathrm{C}_{6} \mathrm{C}_{2}$ Co6. By using a procedure similar to that described for Co1, Co6 was isolated as a brown powder (0.11 g, 83\%). FT-IR ( $\left.\mathrm{KBr} \mathrm{cm}^{-1}\right): 2962(\mathrm{~m}), 2873(\mathrm{w}), 1612\left(u_{\mathrm{C}=\mathrm{N}}, \mathrm{w}\right)$, $1580(w), 1541(w), 1490(m), 1458(w), 1393(m), 1362(m)$, $1319(w), 1285(w), 1241(m), 1202(w), 1121(w), 1088(w)$, 958 (w), 841 (m), 803 (w), 724 (w). Anal. calcd for $\mathrm{C}_{49} \mathrm{H}_{73} \mathrm{Cl}_{2} \mathrm{CoN}_{3}$ (833.98): C, 70.57; $\mathrm{H}, 8.82 ; \mathrm{N}, 5.04$. Found: $\mathrm{C}$, 70.32; H, 8.89; N, 5.40\%.

\section{Ethylene polymerization}

(a) Ethylene polymerization under 5 or 10 atm $C_{2} H_{4}$. A typical polymerization run at 5 or 10 atm $\mathrm{C}_{2} \mathrm{H}_{4}$ was carried out in a stainless steel autoclave $(250 \mathrm{~mL})$ equipped with a pressure control system, temperature controller and mechanical stirrer. The autoclave was evacuated and back-filled three times with nitrogen and once with ethylene. Freshly distilled toluene ( 25 $\mathrm{mL}$ ) was injected into the autoclave under an atmosphere of ethylene. When the temperature required was reached, the complex $(2.0 \mu \mathrm{mol})$ dissolved in toluene $(25 \mathrm{~mL})$, the required amount of co-catalyst (MAO and MMAO) and more toluene $(50 \mathrm{~mL})$ were successively added by syringe. The autoclave was immediately pressurized to the pre-determined ethylene pressure and the stirring commenced $(400 \mathrm{rpm})$. After the required reaction time, the reactor was cooled with a water bath and the ethylene pressure vented. The reaction mixture was then quenched with $10 \%$ hydrochloric acid/ethanol and the precipitated polymer collected by filtration, washed with ethanol and water and finally dried under reduced pressure at $60^{\circ} \mathrm{C}$ until at constant weight.

(b) Ethylene polymerization under 1 atm $\mathrm{C}_{2} \mathrm{H}_{4}$. The polymerization at $1 \mathrm{~atm}$ ethylene pressure was carried out in a Schlenk tube. Co1 $(1.1 \mathrm{mg}, 2.0 \mu \mathrm{mol})$ was added to the tube followed by toluene $(30 \mathrm{~mL})$ and then the required amount of co-catalyst (MAO, MMAO) introduced by syringe. The solution was then stirred at either $60{ }^{\circ} \mathrm{C}$ or $70{ }^{\circ} \mathrm{C}$ under 1 atm $\mathrm{C}_{2} \mathrm{H}_{4}$. After $30 \mathrm{~min}$, the ethylene pressure was released and the mixture quenched with $10 \%$ hydrochloric acid in ethanol. The resulting precipitate was collected by filtration, washed with ethanol and then dried under reduced pressure at $60{ }^{\circ} \mathrm{C}$ until at constant weight.

\section{X-ray crystallographic studies}

Single crystals of Co2 and Co3 suitable for the X-ray diffraction analysis were grown by layering heptane on a dichloromethane solution of the corresponding complex at room temperature. With graphite monochromated Mo-K $\alpha$ radiation $(\lambda=0.71073 \AA$ ) at $173(2) \mathrm{K}$, the cell parameters were

Table 4 Crystal data and structural refinements for $\mathrm{Co2}$ and $\mathrm{Co} 3$

\begin{tabular}{|c|c|c|}
\hline & $\mathrm{Co2}$ & $\mathrm{Co} 3 \cdot 2 \mathrm{CH}_{2} \mathrm{Cl}_{2}$ \\
\hline Empirical formula & $\mathrm{C}_{33} \mathrm{H}_{40} \mathrm{Cl}_{2} \mathrm{CoN}_{3}$ & $\mathrm{C}_{39} \mathrm{H}_{53} \mathrm{Cl}_{6} \mathrm{CoN}_{3}$ \\
\hline Formula weight & 609.52 & 835.47 \\
\hline Temperature/K & 173 & 173 \\
\hline Wavelength/Å & 0.71073 & 0.71073 \\
\hline Crystal system & monoclinic & monoclinic \\
\hline Space group & $P 2_{1} / \mathrm{n}$ & $\mathrm{C} 2 / \mathrm{c}$ \\
\hline$a / \AA ̊$ & $18.285(4)$ & $50.737(10)$ \\
\hline$b / \AA$ & $9.0803(18)$ & 9.3904(19) \\
\hline$c / \AA ̊$ & $18.993(4)$ & $18.027(4)$ \\
\hline Alpha/ ${ }^{\circ}$ & 90 & 90 \\
\hline Beta $/^{\circ}$ & $99.73(3)$ & $103.26(3)$ \\
\hline Gamm $/^{\circ}$ & 90 & 90 \\
\hline Volume $/ \AA^{3}$ & $3108.2(11)$ & $8360(3)$ \\
\hline$Z$ & 4 & 8 \\
\hline$D_{\text {calcd }} /\left(\mathrm{g} / \mathrm{cm}^{-3}\right)$ & 1.303 & 1.328 \\
\hline$\mu / \mathrm{mm}^{-1}$ & 0.750 & 0.825 \\
\hline$F(000)$ & 1284.0 & 3496.0 \\
\hline Crystal size $/ \mathrm{mm}^{3}$ & $\begin{array}{c}0.551 \times 0.160 \times \\
0.098\end{array}$ & $\begin{array}{c}0.562 \times 0.140 \times \\
0.095\end{array}$ \\
\hline$\vartheta$ range $\left({ }^{\circ}\right)$ & 4.352 to 57.164 & 1.65 to 54.866 \\
\hline Lmiting indices & $\begin{array}{c}-24 \leq \mathrm{h} \leq 24 \\
-11 \leq \mathrm{k} \leq 11 \\
-23 \leq \mathrm{I} \leq 22\end{array}$ & $\begin{array}{c}-65 \leq h \leq 65 \\
-11 \leq k \leq 12 \\
-23 \leq l \leq 23\end{array}$ \\
\hline No. of rflns collected & 20874 & 54170 \\
\hline No. unique rflns & 7063 & 9479 \\
\hline $\mathrm{R}_{\text {int }}$ & 0.0418 & 0.1101 \\
\hline No. of params & 370 & 453 \\
\hline Completeness to $\vartheta$ & 88.9 & 99.3 \\
\hline Goodness of fit on $F^{2}$ & 1.113 & 1.265 \\
\hline $\begin{array}{l}\text { Final } R \text { indexes } \\
\qquad[/>=2 \sigma(I)]\end{array}$ & $\begin{array}{c}R_{1}=0.0613 \\
w R_{2}=0.1392\end{array}$ & $\begin{array}{c}R_{1}=0.1107 \\
w R_{2}=0.2280\end{array}$ \\
\hline Final $R$ indexes (all data) & $\begin{array}{c}R_{1}=0.0688 \\
w R_{2}=0.1445\end{array}$ & $\begin{array}{c}R_{1}=0.1209 \\
w R_{2}=0.2340\end{array}$ \\
\hline $\begin{array}{c}\text { Largest diff. peak and } \\
\text { hole } /\left(\mathrm{e} \AA^{-3}\right)\end{array}$ & $0.86 /-0.40$ & $1.31 /-0.91$ \\
\hline
\end{tabular}

polarization effects and empirical absorption. The structures were solved by direct methods and refined by full-matrix least squares on 
$F^{2}$. All hydrogen atoms were placed in calculated positions. Structure solution and refinement were performed by using the SHELXL-97 package.52,53 Details of the X-ray structure determinations and refinements are provided in Table 4.

\section{Conflicts of interest}

There are no conflicts to declare.

\section{Acknowledgements}

This work was supported by the National Natural Science Foundation of China (No. 21871275 and 51473170). GAS thanks the Chinese Academy of Sciences for a President's International Fellowship for Visiting Scientists.

\section{Notes and References}

1 B. L. Small, M. Brookhart and A. M. A. Bennett, J. Am. Chem Soc., 1998, 120, 4049-4050.

2 G. J. P. Britovsek, V. C. Gibson, B. S. Kimberley, P. J. Maddox S. J. McTavish, G. A. Solan, A. J. P. White and D. J. Williams, Chem. Commun., 1998, 849-850.

3 V. C. Gibson and S. K. Spitzmesser, Chem. Rev., 2003, 103 283-316.

4 G. J. P. Britovsek, V. C. Gibson and Wass, D. F. Angew. Chem. Int. Ed., 1999, 38, 428-447.

5 S. D. Ittel, L. K. Johnson and M. Brookhart, Chem. Rev., 2000, 100, 1169-1203.

6 W.-H. Sun, W. Zhao, J. Yu, W. Zhang, X. Hao and C. Redshaw, Macromol. Chem. Phys., 2012, 213, 1266-1273.

7 Q. Xing, T. Zhao, Y. Qiao, L. Wang, C. Redshaw and W.-H. Sun, RSC Adv., 2013, 3, 26184-26193.

8 Q. Xing, T. Zhao, S. Du, W. Yang, T. Liang, C. Redshaw and W. H. Sun, Organometallics, 2014, 33, 1382-1388.

9 X. Cao, F. He, W. Zhao, Z. Cai, X. Hao, T. Shiono, C. Redshaw and Sun, W.-H. Polymer, 2012, 53, 1870-1880.

10 S. Wang, B. Li, T. Liang, C. Redshaw, Y. Li and W. H. Sun, Dalton Trans., 2013, 42, 9188-9197.

11 S. Wang, W. Zhao, X. Hao, B. Li, C. Redshaw, Y. Li and W.-H. Sun, J. Organomet. Chem., 2013, 731, 78-84.

12 F. Huang, Q. Xing, T. Liang, Z. Flisak, B. Ye, X. Hu, W. Yang and W.-H. Sun, Dalton Trans., 2014, 43, 16818-16829.

13 S. Zhang, Q. Xing and W-H. Sun, RSC Adv., 2016, 6, 7217072176.

14 (a) Q. Mahmood, J. Guo, W. Zhang, Y. Ma, T. Liang and W.-H. Sun, Organometallics, 2018, 37, 957-970; (b) Q. Mahmood, Y. Ma, X. Hao and W.-H. Sun, Appl. Organomet. Chem., 2019, 33, e4857.

15 H. Suo, I. I. Oleynik, C. Bariashir, I. V. Oleynik, Z. Wang, G. A Solan, Y. Ma, T. Liang and W.-H. Sun, Polymer, 2018, 149, 45 54.

16 Z. Wang, G. A. Solan, Q. Mahmood, Q. Liu, Y. Ma, X. Hao and W.-H. Sun, Organometallics, 2018, 37, 380-389.

17 Z. Wang, R. Zhang, W. Zhang, G. A. Solan, Q. Liu, T. Liang and W.-H. Sun, Catal. Sci. Technol., 2019, DOI: 10.1039/c9cy00293f

18 Z. Flisak and W.-H. Sun, ACS Catal., 2015, 5, 4713-4724.

19 S. Gao, Inorg. Chem. Front., 2015, 2, 7.

20 V. C. Gibson, C. Redshaw and G. A. Solan, Chem. Rev., 2007, 107, 1745-1776.

21 V. C. Gibson and G. A. Solan, Top. Organomet. Chem., 2009, 26, 107-158.
22 V. C. Gibson and G. A. Solan, in Catalysis without Precious Metals (Ed. R.M. Bullock), Wiley-VCH, Weinheim, 2010, 111141.

23 C. Bianchini, G. Giambastiani, I. G. Rios, G. Mantovani, A. Meli, A. M. Segarra, Coord. Chem. Rev., 2006, 250, 13911418

24 C. Bianchini, G. Giambastiani, L. Luconi and A. Meli, Coord. Chem. Rev., 2010, 254, 431-455.

25 W. Zhang, W.-H. Sun and C. Redshaw, Dalton Trans., 2013 42, 8988-8997.

26 Z. Wang, G. A. Solan, W. Zhang and W.-H. Sun, Coord. Chem. Rev., 2018, 363, 92-108.

27 L. Guo, M. Zada, W. Zhang, A. Vignesh, D. Zhu, Y. Ma, T. Liang and W.-H. Sun, Dalton Trans., 2019, DOI: 10.1039/C9DT01109A

28 V. K. Appukuttan, Y. Liu, B. C. Son, C.-S. Ha, H. Suh and I. Kim, Organometallics, 2011, 30, 2285-2294.

29 W. Zhang, W. Chai, W.-H. Sun, X. Hu, C. Redshaw and X. Hao, Organometallics, 2012, 31, 5039-5048.

30 W.-H. Sun, S. Kong, W. Chai, T. Shiono, C. Redshaw, X. Hu, C. Guo and X. Hao, Appl. Catal. A: Gen., 2012, 447-448, 67-73.

31 Y. Huang, R. Zhang, T. Liang, X. Hu, G. A. Solan and W.-H. Sun, Organometallics, 2019, 38, 1143-1150.

32 J. Ba, S. Du, E. Yue, X. Hu, Z. Flisak and W-H. Sun, RSC Adv., 2015, 5, 32720-32729.

33 F. Huang, W. Zhang, E. Yue, T. Liang, X. Hu and W.-H. Sun, Dalton Trans., 2016, 45, 657-666.

34 Y. Zhang, H. Suo, F. Huang, T. Liang, X. Hu and W.-H. Sun, J. Polym. Sci. Part A: Polym. Chem., 2017, 55, 830-842.

35 F. Huang, W. Zhang, Y. Sun, X. Hu, G. A. Solan and W.-H. Sun, New J. Chem., 2016, 40, 8012-8023.

36 J. Guo, Z. Wang, W. Zhang, I. I. Oleynik, A. Vignesh, I. V. Oleynik, X. Hu, Y. Sun and W.-H. Sun, Molecules, 2019, 24 1176.

37 Y. Xie, H. Huang, W. Mo, X. Fan, Z. Shen, Z. Shen, N. Sun, B. $\mathrm{Hu}$ and X. Hu, Tetrahedron: Asymmetr., 2009, 20, 1425-1432

38 J.-Y. Liu, Y.-S. Li, J.-Y. Liu, Z.-S. Li, J. Mol. Catal. A: Chem., 2006, 244, 99-104.

39 D. Gong, W. Liu, T. Chen, Z.-R. Chen, K.-W. Huang, J. Mol. Catal. A: Chem., 2014, 395, 100-107.

40 Z. Hao, B. Xu, W. Gao, Y. Han, G. Zeng, J. Zhang, G. Li and Y. Mu, Organometallics, 2015, 34, 2783-2790.

41 S. Du, S. Kong, Q. Shi, J. Mao, C. Guo, J. Yi, T. Liang and W.-H. Sun, Organometallics, 2015, 34, 582-590.

42 Y. Zhang, C. Huang, X. Hao, X. Hu and W.-H. Sun, RSC Adv., 2016, 6, 91401-91408.

43 C. Huang, S. Du, G. A. Solan, Y. Sun and W.-H. Sun, Dalton Trans., 2017, 46, 6948-6957.

44 W. Krauss and W. Gestrich, Chem.-Tech., 1977, 6, 513-516.

45 D. J. Jones, V. C. Gibson, S. M. Green, P. J. Maddox, A. J. P. White and D. J. Williams, J. Am. Chem. Soc., 2005, 127 11037-11046.

46 A. K. Tomov, V. C. Gibson, G. J. P. Britovsek, R. J. Long, M. van Meurs, D. J. Jones, K. P. Tellmann and J. J. Chirinos, Organometallics, 2009, 28, 7033-7040.

47 S. Du, X. Wang, W. Zhang, Z. Flisak, Y. Sun and W-H. Sun, Polym. Chem., 2016, 7, 4188-4197.

48 C. Huang, Y. Zhang, G. A. Solan, Y. Ma, X. Hu, Y. Sun and W.H. Sun, Eur. J. Inorg. Chem., 2017, 2017, 4158-4166.

49 G. B. Galland, Ra. Quijada, R. Rojas, G. Bazan and Z. J. A. Komon, Macromolecules, 2002, 35, 339-345.

50 E. W. Hansen, R. Blom and O. M. Bade, Polymer, 1997, 38 4295-4304.

51 M. De Pooter, P. B. Smith, K. K. Dohrer, K. F. Bennett, M. D. Meadows, C. G. Smith, H. P. Schouwenaars and R. A Geerards, J. Appl. Polym. Sci., 1991, 42, 399-408.

52 G. M. Sheldrick, Acta Crystallogr., 2015, A71, 3-8.

53 G. M. Sheldrick, Acta Crystallogr., 2015, C71, 3-8. 
